\title{
EU Enlargement and the Portuguese Economy
}

\author{
Frank Barry*, Nuno Crespo** and M. Paula Fontoura*** \\ * University College Dublin \\ ** ISEG, Technical University of Lisbon \\ *** CEDIN and ISEG, Technical University of Lisbon
}

\begin{abstract}
Ten states, primarily from Central and Eastern Europe, will be admitted to the EU in 2004. The present paper assesses the competitiveness implications of this enlargement for Portugal. Four specific topics are considered: the trade and industry effects, the implications for Portugal's ability to attract FDI, the likely levels and consequences of immigration from Central and Eastern Europe and the implications for Portugal's budgetary relations with the rest of the EU.
\end{abstract}

JEL Codes: F14, F15, F21, F22

Keywords: European Union, Enlargement, Portugal, Central and Eastern European Countries.

Correspondence address: fontoura@iseg.utl.pt

The financial support of the Fundação para a Ciência e a Tecnologia /MCT under SFRH/BD/6412/2001 (supported by the European Social Fund) is gratefully acknowledged. The authors are indebted to João Peixoto for helpful comments. 


\section{Introduction}

After the accession of Ireland, U.K. and Denmark in the 1970's, Greece, Spain and Portugal in the 1980's and Sweden, Finland and Austria in the 1990's, the EU's border is now expanding eastwards. Eight Central and Eastern European countries - the Czech Republic, Hungary, Poland, Slovenia, Estonia, Latvia, Lithuania, Slovakia (the CEEC8) - plus Malta and Cyprus will be full members in 2004. Romania and Bulgaria are expected to accede in 2007. The opening of negotiations with Turkey remains conditional on its meeting the political criteria for accession. Given the small size of the Maltese and Cypriot economies, previous analyses on the subject have concentrated on the implications of the accession of the CEEC only. This is also the position we adopt.

With Eastern enlargement, a region of about 100 million inhabitants emerging from almost half a century of Soviet domination will be integrated into the EU. A process of economic integration as profound and extensive as this will have far-reaching implications for the current EU member states. As in any similar liberalisation process, the lifting of trade barriers already accomplished under the Europe Agreements allows for productive factors to be reallocated to more efficient activities, reflected in the productive specialisation of the CEE countries and, by extension, in the volume and pattern of their trade. ${ }^{1}$ International direct investment flows - in terms of volume and geographical and sectoral distribution - will be further affected by accession, as will overall industrial location. But the particular past of the CEE candidates poses entirely new issues for the EU. First of all, the applicants are in a process of transition to the market economy and much of the analysis of the impact of enlargement depends upon assessments of the extent to which the process has been completed. Secondly, the purpose is to integrate into the "rich man's club" countries starting from very low levels of income per head (39\% of the average in the EU15). The accession of Greece, Portugal and Spain in the 1980 s also brought relatively low-income partners into the Union,

\footnotetext{
${ }^{1}$ A total of ten association agreements were signed with the EU between 1991 and 1996, leading to a liberalisation of market access for industrial goods over a period of (a maximum) 10 years for Eastern countries and five years for the EU. The former had already opted for relatively low tariffs and quotas after shaking off communism however (Pelkmans, 2001, section 18.4). These agreements also include explicit references to the eventual accomplishment of the free movement of services, capital and, conditionally, of persons.
} 
though per-capita PPP-based income levels in those countries were already at about 62 percent of the levels pertaining to EU incumbents at that time.

The low level of economic development of the Eastern candidate countries and

the relatively large size of their agricultural sectors lie at the heart of most of the "high profile" enlargement issues, such as the planned extension of the structural funds and Common Agricultural Policy programmes, east-west migration and labour-market effects. Thus, the pressure has been to establish transition periods before new members achieve full access to regional and agricultural programmes. For example, the capping of structural fund transfers to new members at the $4 \%$ of their GDP, as decided by the Berlin Council, is likely to be extended beyond 2006. Recent studies suggest that enlargement should not put an unbearable strain on the EU budget, though the distribution across member states is important. Accession of the CEEC is also expected to lead to significant EU migration inflows, with the possibility of wage reductions and job losses for unskilled incumbents.

Many studies have demonstrated that all of these issues are manageable and should not cause substantial economic problems to the Union as a whole. Besides, the benefits in terms of further trade integration and migration are substantial and will largely outweigh the costs of accession at the EU aggregate level (Baldwin et al.,1997; Lejour et al., 2001; Breuss, 2001). However difficulties may arise in the case of particular members, particularly Portugal, as suggested, for instance, by Baldwin et al.(1997).

The present paper is a broad reflection on the economic impact of Eastern enlargement on the Portuguese economy. Section 2 deals with external trade; Section 3 with inward FDI; Section 4 with migration flows and Section 5 with the Structural and Cohesion Fund programmes. Section 6 concludes.

\section{Trade Effects of Enlargement}

After Portuguese accession to the EU an important change in the country's export structure occurred. As shown in Table 1, the share of the labour intensive traditional sectors (textiles, clothing, footwear) decreased, while the share of machinery, apparatus, vehicle and other transport equipment - the sectors with the highest FDI inflows in terms 
of foreign equity in Portuguese manufacturing - increased. In 2000, the weight of this last group clearly overcame the traditional one (by 10 percentage points), a notable feature considering the predominance of the latter in the past. However, at the end of the 1990s the weight of the traditional sector in total exports was still much higher for Portugal than was the case for the EU average (respectively $30 \%$ and $6 \%$ in the second half of the 1990s).

Table 1:Structure of Portuguese exports (manufacturing industry)

\begin{tabular}{|l|r|r|r|}
\hline $\begin{array}{l}\text { Product groups } \\
\text { (CN chapters) }\end{array}$ & \multicolumn{1}{|c|}{1995} & 1998 & \multicolumn{1}{|c|}{2000} \\
\hline Agricultural products & 3.0 & 2.6 & 3.0 \\
Foodstuffs & 4.4 & 3.7 & 3.9 \\
Mineral fuels & 3.1 & 0.7 & 2.6 \\
Chemical products & 3.6 & 3.2 & 4.0 \\
Plastics, Rubber & 2.6 & 3.1 & 3.5 \\
Raw hides and skins, Leather & 0.4 & 0.3 & 0.4 \\
Wood, Cork & 4.8 & 4.1 & 4.9 \\
Cellulose pulp, Paper & 6.3 & 4.9 & 5.4 \\
Textile materials & 7.3 & 6.8 & 7.1 \\
Clothing & 16.5 & 15.7 & 11.5 \\
Footwear & 8.0 & 7.7 & 6.1 \\
Mineral products & 5.7 & 4.2 & 4.1 \\
Base metals & 3.9 & 4.4 & 5.4 \\
Machinery, Apparatus & 17.1 & 16.9 & 19.9 \\
Vehicles, Other transport equipment & 9.6 & 18.1 & 14.7 \\
Optical and precision instruments & 1.2 & 1.0 & 0.8 \\
Other products & 2.5 & 2.6 & 2.7 \\
\hline
\end{tabular}

Source: Instituto Nacional de Estatística (INE)

The Portuguese economy is highly open (with exports and imports summing to 75 percent of GDP), with most of the export and import flows taking place with the EU15 (80.3 and $75.1 \%$ of total exports and imports, respectively, in 2000). This exceeds the EU15 average by almost 20 percentage points (again evaluated over the second half of the 1990s).

With the elimination of trade barriers between incumbents and accession states, two effects on the Portuguese economy may be predicted: a trade creation effect in terms of an increase in bilateral flows with the CEEC, and a shift effect, as CEE countries displace some Portuguese exports to EU markets. ${ }^{2}$

\footnotetext{
${ }^{2}$ We do not focus on intra-industry and quality aspects of EU-CEE trade, but Caetano et al. (2002) predicts a deepening of intra-industry trade, mainly of the vertical type.
} 
The extent of pre-accession integration of Eastern applicants is already substantial as the Europe Agreements have led to the removal of tariffs on industrial products (though impediments to trade in agriculture and food processing remain). Thus many of the static trade effects of enlargement are already noticeable.

As shown in Table 2, the weight of CEE countries in Portuguese external trade has increased from the very modest levels achieved in 1995. However, in 2000, the CEEC accounted for no more than $1.22 \%$ of Portuguese exports and $1.29 \%$ of imports. Among the CEE countries, Poland, the Czech Republic and Hungary are Portugal's main trading partners (accounting for $82.8 \%$ of total exports to the CEEC and $72.9 \%$ of total imports from the CEEC). This fact suggests that we focus particular attention on these three countries.

Table 2: Portuguese external trade with EU and CEEC

\begin{tabular}{|l|r|r|r|r|r|r|}
\hline \multirow{2}{*}{ E.U. } & \multicolumn{3}{|c|}{ \% of total exports } & \multicolumn{3}{c|}{ \% of total imports } \\
\cline { 2 - 7 } & 1995 & \multicolumn{1}{|c|}{1998} & \multicolumn{1}{c|}{2000} & \multicolumn{1}{c|}{1995} & \multicolumn{1}{c|}{1998} & \multicolumn{1}{c|}{2000} \\
\hline CEEC & 80.60 & 82.00 & 80.27 & 74.52 & 78.13 & 75.12 \\
\hline C. Republic & 0.65 & 0.85 & 1.22 & 0.50 & 0.68 & 1.29 \\
\hline Hungary & 0.05 & 0.09 & 0.16 & 0.08 & 0.19 & 0.31 \\
\hline Poland & 0.13 & 0.30 & 0.45 & 0.04 & 0.17 & 0.15 \\
\hline
\end{tabular}

Source: Instituto Nacional de Estatística (INE)

Although Portuguese trade with the CEEC increased at a much higher rate than with other partners, the importance of these countries for Portuguese external trade remains small. It is noteworthy that imports from CEEC have increased at a higher speed than exports towards these markets, unlike in the Irish case for example. Other EU countries also registered a significant increase in trade with the CEEC - particularly Germany, Austria, France and Italy. ${ }^{3}$ The same three CEE countries account for the bulk of trade with the rest of the EU also.

Let us now evaluate the second effect. Is it reasonable to consider a significant diversion of EU imports away from Portugal and towards the CEE countries? It seems to us that the answer is a qualified yes. The reasons are twofold: the high degree of similarity between the Portuguese export structure and that of the CEEC, and the fact that 
for the majority of Portuguese export sectors, CEEC became progressively more competitive during the second half of the 1990's, as shown by an analysis of EU market share data.

Similarities in export structures are evaluated using the Finger-Kreinin export overlapping index. ${ }^{4}$ Table 3 shows the index for exports to the EU market of countries "a" and "b", where "a" is a EU member and "b" a CEE country (including Bulgaria and Romania). An index value of 1 would indicate that the relative weight of the products considered in total exports is the same for both economies, while a value of zero would indicate a complete difference.

Table 3: Finger-Kreinin export overlapping index (2000)

\begin{tabular}{|l|r|l|r|r|r|r|r|r|r|r|r|}
\hline & C.Rep & Hung & Polan & Slove & Slovaq & Eston & Latvia & Lithu. & Bulg. & Rom. & CEEC \\
\hline France & 0.651 & 0.612 & 0.593 & 0.594 & 0.600 & 0.322 & 0.206 & 0.327 & 0.406 & 0.392 & 0.663 \\
\hline Germ. & 0.667 & 0.581 & 0.582 & 0.615 & 0.611 & 0.291 & 0.193 & 0.299 & 0.363 & 0.365 & 0.660 \\
\hline Italy & 0.717 & 0.587 & 0.639 & 0.669 & 0.658 & 0.340 & 0.264 & 0.380 & 0.445 & 0.449 & 0.697 \\
\hline Neth. & 0.443 & 0.548 & 0.453 & 0.403 & 0.430 & 0.396 & 0.293 & 0.379 & 0.343 & 0.328 & 0.505 \\
\hline Bel-Lu. & 0.624 & 0.542 & 0.589 & 0.577 & 0.612 & 0.343 & 0.248 & 0.359 & 0.445 & 0.377 & 0.630 \\
\hline U.K. & 0.535 & 0.646 & 0.505 & 0.488 & 0.500 & 0.364 & 0.232 & 0.285 & 0.329 & 0.342 & 0.583 \\
\hline Aust. & 0.697 & 0.587 & 0.670 & 0.642 & 0.632 & 0.341 & 0.241 & 0.352 & 0.416 & 0.420 & 0.692 \\
\hline Denm. & 0.556 & 0.526 & 0.534 & 0.507 & 0.490 & 0.436 & 0.307 & 0.370 & 0.395 & 0.428 & 0.598 \\
\hline Sweden & 0.549 & 0.493 & 0.521 & 0.513 & 0.539 & 0.388 & 0.223 & 0.299 & 0.358 & 0.376 & 0.559 \\
\hline Finland & 0.374 & 0.349 & 0.377 & 0.385 & 0.425 & 0.503 & 0.250 & 0.285 & 0.305 & 0.353 & 0.427 \\
\hline Ireland & 0.271 & 0.416 & 0.257 & 0.228 & 0.228 & 0.226 & 0.116 & 0.204 & 0.219 & 0.232 & 0.301 \\
\hline Spain & 0.668 & 0.558 & 0.599 & 0.622 & 0.698 & 0.295 & 0.206 & 0.320 & 0.395 & 0.372 & 0.633 \\
\hline Greece & 0.313 & 0.316 & 0.377 & 0.348 & 0.349 & 0.283 & 0.296 & 0.389 & 0.487 & 0.404 & 0.385 \\
\hline Portugal & 0.633 & 0.562 & 0.632 & 0.629 & 0.667 & 0.357 & 0.304 & 0.450 & 0.501 & 0.525 & 0.667 \\
\hline
\end{tabular}

Source: Own calculations based on Chelem

Portugal has, together with France, Germany, Italy, Austria and Spain the highest value. Being so, these countries can potentially be significantly affected by this shift effect. Furthermore, it is worthwhile noting that, among these countries, Portugal is the one that stands to benefit least from the first effect analysed above.

To compare the competitiveness of Portuguese and CEEC exports in the EU15 market we consider two years: 1995 and 2000. The latter year is the most recent for

\footnotetext{
3 These countries are the main trade partners of CEEC with Germany at the top, responsible in 1999, for about $25 \%$ of imports from CEEC and receiving about 33\% of their exports (Martín et al. , 2002).

${ }^{4}$ The Finger-Kreinin index is given by: $\sum \min \left(\mathrm{S}_{\mathrm{i}}{ }^{\mathrm{ac}}, \mathrm{S}_{\mathrm{i}}{ }^{\mathrm{bc}}\right)$ where $\mathrm{S}_{\mathrm{i}}{ }^{\mathrm{ac}}$ is the weight of product $\mathrm{i}$ in country a exports to country $\mathrm{c}$ and $\mathrm{S}_{\mathrm{i}}^{\mathrm{bc}}$ is the weight of product $\mathrm{i}$ in country b exports to country $\mathrm{c}$. In this study, "country" c is the EU.
} 
which data are available, and the former is chosen as the start date because the Europe Agreements had just come into force at that time. Exports to the EU during this period will be evaluated in terms of the dynamism of EU demand and also by making use of two typologies that allow us to aggregate the different sectors according to relevant characteristics - the so-called specialisation factors and the level of technology. ${ }^{5}$ We use the Chelem data set elaborated by CEPII (Centre d'Études Prospectives et d'Informations Internationales) which gives information on trade flows disaggregated into 72 sectors. For purposes of comparison we use the other EU Cohesion countries - Spain, Greece and Ireland.

Let us start with the demand-dynamism criterion. Based on average annual growth in EU imports between 1995 and 2000, we distinguish three categories: dynamic demand (a growth rate above $5 \%$ ), sluggish demand (a positive growth rate but below $5 \%$ ) and declining demand (a negative growth rate). The results are presented in Table 4.

Table 4: Exports to the EU by EU demand dynamism ( \% of total exports)

\begin{tabular}{|l|r|r|r|r|r|r|}
\hline & \multicolumn{3}{|c|}{1995} & \multicolumn{3}{|c|}{2000} \\
\cline { 2 - 7 } & $\begin{array}{c}\text { Dynamic } \\
\text { demand }\end{array}$ & $\begin{array}{c}\text { Slow growth } \\
\text { Demand }\end{array}$ & $\begin{array}{c}\text { Declining } \\
\text { demand }\end{array}$ & $\begin{array}{c}\text { Dynamic } \\
\text { demand }\end{array}$ & $\begin{array}{c}\text { Slow growth } \\
\text { Demand }\end{array}$ & $\begin{array}{c}\text { Declining } \\
\text { demand }\end{array}$ \\
\hline C. Republic & 7.2 & 45.5 & 47.3 & 8.2 & 62.4 & 29.4 \\
\hline Hungary & 9.7 & 47.2 & 43.1 & 22.1 & 56.5 & 21.4 \\
\hline Poland & 5.3 & 38.0 & 56.7 & 6.4 & 53.7 & 39.9 \\
\hline CEEC(10) & 7.8 & 40.5 & 51.7 & 12.9 & 52.3 & 34.8 \\
\hline Ireland & 38.3 & 34.3 & 27.4 & 46.7 & 39.7 & 13.6 \\
\hline Greece & 8.4 & 28.7 & 62.9 & 9.3 & 29.0 & 61.7 \\
\hline Spain & 6.7 & 53.5 & 39.8 & 9.1 & 54.6 & 36.3 \\
\hline Portugal & 5.5 & 54.6 & 39.9 & 5.3 & 58.4 & 36.3 \\
\hline
\end{tabular}

Source: Own calculations based on Chelem

CEE countries, and Hungary in particular, increased their exports in sectors in which EU demand is dynamic. The same is true of the Cohesion countries other than Portugal, where exports in dynamic sectors declined in importance. In 2000, Portugal displays the lowest value in this group of sectors.

More important than the relative weight of the different categories in total exports is the evolution, for each of them, of the market share of the different countries in the European economic area. Table 5 presents these results.

\footnotetext{
${ }^{5}$ The classification of sectors in each category is based on Fernandes (2002). In both typologies, two
} 
Table 5: EU market share by EU demand dynamism

\begin{tabular}{|c|c|c|c|c|c|c|c|c|}
\hline & \multicolumn{4}{|c|}{1995} & \multicolumn{4}{|c|}{2000} \\
\hline & $\begin{array}{c}\text { Dynamic } \\
\text { demand }\end{array}$ & $\begin{array}{c}\text { Slow } \\
\text { growth } \\
\text { demand }\end{array}$ & $\begin{array}{l}\text { Declining } \\
\text { demand }\end{array}$ & Total & $\begin{array}{c}\text { Dynamic } \\
\text { demand }\end{array}$ & $\begin{array}{c}\text { Slow } \\
\text { growth } \\
\text { demand }\end{array}$ & $\begin{array}{l}\text { Declining } \\
\text { demand }\end{array}$ & Total \\
\hline C. Repub. & 0.21 & 0.65 & 0.77 & 0.60 & 0.24 & 1.30 & 0.90 & 0.87 \\
\hline Hungary & 0.24 & 0.57 & 0.59 & 0.51 & 0.65 & 1.19 & 0.66 & 0.87 \\
\hline Poland & 0.21 & 0.73 & 1.25 & 0.82 & 0.20 & 1.23 & 1.33 & 0.95 \\
\hline CEEC(10) & 1.12 & 2.87 & 4.18 & 2.99 & 1.71 & 5.00 & 4.84 & 3.97 \\
\hline Ireland & 3.09 & 1.37 & 1.25 & 1.68 & 3.37 & 2.07 & 1.03 & 2.16 \\
\hline Greece & 0.14 & 0.24 & 0.59 & 0.35 & 0.08 & 0.17 & 0.53 & 0.24 \\
\hline Spain & 1.12 & 4.39 & 3.73 & 3.46 & 1.11 & 4.80 & 4.64 & 3.65 \\
\hline Portugal & 0.25 & 1.25 & 1.04 & 0.96 & 0.15 & 1.21 & 1.09 & 0.86 \\
\hline
\end{tabular}

Source: Own calculations based on Chelem

In global terms, of the countries considered, only two lost market share in the EU between 1995 and 2000: Greece and Portugal. ${ }^{6}$ The Portuguese evolution is mainly explained by its loss of relative position in the dynamic-demand sectors, though the same occurred to a lesser extent in the sluggish-demand sectors. Only in the declining-demand sectors was there a small increase. CEE countries, on the other hand, registered significant improvements in their positions not only in global terms but also in all of the segments considered. Of course the CEEC are not the only cause of Portugal's declining market share: one must also mention the effects of the tariff and non - tariff reductions of the Uruguay Round.

Next we categorise EU imports in terms of the main determining factor, categorised as: natural resources, labour costs, scale economies, product differentiation and R\&D. ${ }^{7}$ Table 6 shows the weight of the sectors in each one of these categories in the total exports of each country.

sectors are excluded due to their heterogeneity.

${ }^{6}$ Concerning the Portuguese situation, the Ministry of Economy (2002) presents a similar result.

${ }^{7}$ This typology, and the next one to be considered, may be criticised on various grounds: firstly, that competitiveness depends on factors other than the main one considered and, secondly, that the factors describing a particular sector may differ across countries. Despite these limitations the typologies still appear to us to be useful. 
Table 6: Exports to the EU by specialisation factors (as a share of total exports)

\begin{tabular}{|l|r|r|r|r|r|r|r|r|r|r|}
\hline & \multicolumn{4}{|c|}{1995} & \multicolumn{3}{|c|}{2000} \\
\cline { 2 - 11 } & $\begin{array}{c}\text { Nat. } \\
\text { Resou. }\end{array}$ & $\begin{array}{c}\text { Labour } \\
\text { costs }\end{array}$ & $\begin{array}{c}\text { Scale } \\
\text { econ. }\end{array}$ & $\begin{array}{c}\text { Prod. } \\
\text { Differ. }\end{array}$ & R\&D & $\begin{array}{c}\text { Nat. } \\
\text { Resou. }\end{array}$ & $\begin{array}{c}\text { Labour } \\
\text { costs }\end{array}$ & $\begin{array}{c}\text { Scale } \\
\text { econ. }\end{array}$ & $\begin{array}{c}\text { Prod. } \\
\text { Differ. }\end{array}$ & R\&D \\
\hline C. Republic & 18.4 & 21.1 & 28.2 & 17.8 & 14.5 & 10.5 & 14.7 & 35.4 & 24.3 & 15.1 \\
\hline Hungary & 20.3 & 23.5 & 16.7 & 24.9 & 14.6 & 9.5 & 12.4 & 17.3 & 28.4 & 32.4 \\
\hline Poland & 26.4 & 35.3 & 20.1 & 8.3 & 9.9 & 19.6 & 27.5 & 24.8 & 16.5 & 11.6 \\
\hline CEEE(10) & 21.9 & 30.6 & 22.6 & 13.6 & 11.3 & 15.0 & 24.3 & 24.2 & 19.3 & 17.2 \\
\hline Ireland & 27.7 & 5.6 & 8.1 & 7.6 & 51.0 & 13.1 & 3.0 & 9.6 & 6.6 & 67.7 \\
\hline Greece & 43.7 & 38.6 & 8.7 & 3.6 & 5.4 & 45.0 & 35.7 & 8.3 & 4.5 & 6.5 \\
\hline Spain & 23.5 & 10.1 & 44.5 & 10.1 & 11.8 & 22.4 & 9.9 & 43.6 & 10.5 & 13.6 \\
\hline Portugal & 20.9 & 35.4 & 18.9 & 11.7 & 13.1 & 17.8 & 30.9 & 26.4 & 11.4 & 13.5 \\
\hline
\end{tabular}

Source: Own calculations based on Chelem

In 2000, among the countries considered, Portugal and Greece are those with the highest weight in the group of sectors in which labour costs are the key element, above the values of the CEEC and particularly those of the Czech Republic and Hungary. In sectors in which the main factor is product differentiation or $\mathrm{R} \& \mathrm{D}$, on the other hand, the CEEC have a higher weight than Portugal. In terms of evolution, the share of these sectors in CEE exports increased considerably whilst in Portugal it remained practically unchanged. Table 7 uses the same typology but now for the EU market share.

Table 7: Market share in the EU by specialisation factors

\begin{tabular}{|c|c|c|c|c|c|c|c|c|c|c|}
\hline & \multicolumn{5}{|c|}{1995} & \multicolumn{5}{|c|}{2000} \\
\hline & $\begin{array}{l}\text { Nat. } \\
\text { Resou. }\end{array}$ & $\begin{array}{l}\text { Labour } \\
\text { costs }\end{array}$ & $\begin{array}{l}\text { Scale } \\
\text { econ. }\end{array}$ & $\begin{array}{l}\text { Prod. } \\
\text { Diffe }\end{array}$ & $\begin{array}{c}\mathrm{R} \& \\
\mathrm{D}\end{array}$ & $\begin{array}{l}\text { Nat. } \\
\text { Resou. }\end{array}$ & $\begin{array}{c}\text { Labour } \\
\text { costs }\end{array}$ & $\begin{array}{l}\text { Scale } \\
\text { econ. }\end{array}$ & $\begin{array}{l}\text { Prod. } \\
\text { Differ. }\end{array}$ & $R \& D$ \\
\hline C. Republic & 0.43 & 0.95 & 0.69 & 0.84 & 0.37 & 0.39 & 1.11 & 1.39 & 1.67 & 0.47 \\
\hline Hungary & 0.41 & 0.91 & 0.35 & 1.02 & 0.32 & 0.36 & 0.97 & 0.70 & 2.02 & 1.04 \\
\hline Poland & 0.86 & 2.20 & 0.68 & 0.55 & 0.35 & 0.81 & 2.31 & 1.08 & 1.26 & 0.40 \\
\hline CEEC(10) & 2.61 & 6.95 & 2.80 & 3.26 & 1.47 & 2.58 & 8.53 & 4.42 & 6.16 & 2.48 \\
\hline Ireland & 1.61 & 0.62 & 0.49 & 0.89 & 3.23 & 1.10 & 0.51 & 0.86 & 1.03 & 4.80 \\
\hline Greece & 0.60 & 1.01 & 0.12 & 0.10 & 0.08 & 0.47 & 0.76 & 0.09 & 0.09 & 0.06 \\
\hline Spain & 3.27 & 2.69 & 6.43 & 2.82 & 1.79 & 3.55 & 3.21 & 7.33 & 3.09 & 1.81 \\
\hline Portugal & 0.82 & 2.64 & 0.76 & 0.91 & 0.56 & 0.67 & 2.38 & 1.06 & 0.80 & 0.43 \\
\hline $\begin{array}{l}\text { Growth rate } \\
(1995-2000)^{*}\end{array}$ & 1.46 & 0.13 & 0.96 & 3.01 & 6.87 & & & & & \\
\hline
\end{tabular}

* average annual growth rate

Source: Own calculations based on Chelem

The groups of sectors where product differentiation and $R \& D$ are the decisive determinants are those where demand in the European market grew fastest between 1995 and 2000. Table 7 shows that in both cases Portugal (and Greece) lost market share. In 
fact, other than in sectors in which scale economies are the key factor, the Portuguese position deteriorated in all categories. On the contrary, CEEC gained market share in all segments other than those in which natural resources are most important (and trade liberalisation, it must be remembered, is less advanced in these sectors). Starting from an unfavourable situation, the Czech Republic and Hungary had already attained, by 2000, a market share higher than the Portuguese one in sectors with more dynamic specialisation factors.

Let us now make the evaluation according to the technological level (high, medium and low), as reported in Table 8.

Table 8: Exports to the EU by technological level (in \% of total exports)

\begin{tabular}{|l|r|r|r|r|r|r|}
\hline \multirow{2}{*}{} & \multicolumn{7}{|c|}{1995} & \multicolumn{1}{c|}{2000} \\
\cline { 2 - 7 } & \multicolumn{1}{|c|}{ High } & \multicolumn{1}{c|}{ Medium } & \multicolumn{1}{c|}{ Low } & \multicolumn{1}{c|}{ High } & \multicolumn{1}{c|}{ Medium } & \multicolumn{1}{c|}{ Low } \\
\hline C. Republic & 22.7 & 28.1 & 49.2 & 29.9 & 39.0 & 31.1 \\
\hline Hungary & 24.4 & 31.4 & 44.2 & 44.0 & 34.2 & 21.8 \\
\hline Poland & 13.5 & 26.8 & 59.7 & 18.9 & 33.0 & 48.1 \\
\hline CEEE(10) & 17.1 & 27.5 & 55.4 & 27.0 & 32.3 & 40.7 \\
\hline Ireland & 45.6 & 20.6 & 33.8 & 54.9 & 29.0 & 16.1 \\
\hline Greece & 7.8 & 13.4 & 78.8 & 9.7 & 14.2 & 76.1 \\
\hline Spain & 15.9 & 46.6 & 37.5 & 17.9 & 46.7 & 35.4 \\
\hline Portugal & 20.4 & 21.1 & 58.5 & 21.8 & 27.1 & 51.1 \\
\hline
\end{tabular}

Source: Own calculations based on Chelem

In 2000 , low technology exports represented more than $50 \%$ of total Portuguese exports whilst in the case of the CEEC the value was 40.7\%. In Hungary, the figure was as low as $21.8 \%$. In the CEEC (and mainly in Hungary), during the time-period analysed, there was a strong increase in the weight of high technology sectors in total exports. In Portugal, the increase was marginal. Ireland is a special case with $55 \%$ of total exports coming from high technology sectors. The evaluation of market shares according to these criteria is shown in Table 9. 
Table 9 : Market share in the EU by technological level

\begin{tabular}{|l|r|r|r|r|r|r|}
\hline & \multicolumn{7}{|c|}{1995} & \multicolumn{1}{c|}{ 2000 } \\
\cline { 2 - 7 } & \multicolumn{1}{|c|}{ High } & \multicolumn{1}{c|}{ Medium } & \multicolumn{1}{c|}{ Low } & \multicolumn{1}{c|}{ High } & \multicolumn{1}{c|}{ Medium } & \multicolumn{1}{c|}{ Low } \\
\hline C. Republic & 0.50 & 0.53 & 0.73 & 0.82 & 1.13 & 0.75 \\
\hline Hungary & 0.47 & 0.51 & 0.57 & 1.24 & 1.02 & 0.54 \\
\hline Poland & 0.41 & 0.70 & 1.23 & 0.57 & 1.06 & 1.29 \\
\hline CEEE(10) & 1.91 & 2.62 & 4.16 & 4.67 & 4.77 & 4.74 \\
\hline Ireland & 2.48 & 0.96 & 1.24 & 3.41 & 1.92 & 0.89 \\
\hline Greece & 0.10 & 0.15 & 0.68 & 0.08 & 0.12 & 0.52 \\
\hline Spain & 2.08 & 5.18 & 3.29 & 2.09 & 5.78 & 3.67 \\
\hline Portugal & 0.75 & 0.66 & 1.44 & 0.61 & 0.80 & 1.26 \\
\hline Growth rate & $\mathbf{6 . 4 3}$ & $\mathbf{1 . 8 7}$ & $\mathbf{0 . 7 0}$ & & & \\
(1995-2000)* & & & & & & \\
\hline
\end{tabular}

* average annual growth rate

Source: Own calculations based on Chelem

The results are clear: concerning the high technology sectors, Ireland and CEEC improved their positions significantly, Portugal fell substantially while Spain and Greece remained relatively stable. It is also interesting to note that the CEEC gained market share in EU in all sectoral groups, with higher gains recorded in higher technology sectors.

To complement the analysis, we evaluate changes in EU market share by considering those products where Portugal displays high levels of revealed comparative advantage (RCA), as measured by the Balassa export performance index for the EU market. ${ }^{8}$ The sectors where Portugal has, in 2000, the highest RCA values (in decreasing order and considering only sectors with an RCA score greater than 5) are: knitwear, wood products, carpets, leather, consumer electronics and clothing. Other than consumer electronics, all are low-tech sectors in which production is based on low labour costs and, in the case of wood articles, on natural resources. In contrast, consumer electronics is a high technology sector in which R\&D is important. In all six sectors, demand is either sluggish or declining.

The evolution of the market shares of these key-sectors for the Portuguese economy is presented in Table 10.

\footnotetext{
${ }^{8}$ This is the ratio of the weight of sector $\mathrm{i}$ in the exports of country $\mathrm{j}$ to the EU over the weight of sector $\mathrm{i}$ in total EU-country exports.
} 
Table 10: EU market share for the sectors with highest RCA in Portugal

\begin{tabular}{|l|r|r|r|r|r|r|r|r|r|r|}
\hline \multirow{2}{*}{ Sectors } & \multicolumn{2}{|c|}{ Portugal } & \multicolumn{2}{c|}{ CEEC } & \multicolumn{2}{c|}{ C. Republic } & \multicolumn{2}{c|}{ Hungary } & \multicolumn{2}{|c|}{ Poland } \\
\cline { 2 - 12 } & 1995 & 2000 & 1995 & 2000 & 1995 & 2000 & 1995 & 2000 & 1995 & 2000 \\
\hline Knitwear & 6.50 & 4.92 & 5.66 & 7.25 & 0.66 & 0.51 & 1.22 & 1.25 & 1.24 & 1.31 \\
\hline $\begin{array}{l}\text { Wood } \\
\text { articles }\end{array}$ & 5.16 & 4.62 & 11.28 & 13.65 & 1.80 & 1.98 & 0.94 & 1.06 & 4.72 & 5.61 \\
\hline Carpets & 4.27 & 4.25 & 4.91 & 6.60 & 1.31 & 1.75 & 0.68 & 0.50 & 1.54 & 2.23 \\
\hline Leather & 4.72 & 4.59 & 6.05 & 7.04 & 0.98 & 0.57 & 1.16 & 1.22 & 0.98 & 0.84 \\
\hline $\begin{array}{l}\text { Consumer } \\
\text { electronics }\end{array}$ & 3.84 & 3.23 & 1.61 & 9.07 & 0.01 & 0.86 & 1.06 & 5.61 & 0.37 & 2.26 \\
\hline Clothing & 3.57 & 2.67 & 13.54 & 14.84 & 1.04 & 0.83 & 1.52 & 1.30 & 4.80 & 3.69 \\
\hline
\end{tabular}

Source: Own calculations based on Chelem

In all sectors presented in Table 10, Portugal lost market share between 1995 and 2000 whilst the CEEC share expanded. In spite of this, in most cases the improvement in CEEC performance is relatively modest. The exception interestingly is consumer electronics, where both CEEC as a whole and the Czech Republic, Hungary and Poland, individually, increased their market shares substantially.

It is possible that the price-quality structure of Portuguese exports in the EU market corresponds to different market segments as compared to the exports of the CEE countries. Caetano et al. (2002, Table 22) measure the percentages of high, medium and low quality exports in the total EU exports of Portugal and the CEE10 by using the 'trade flow unit value' approach of Freudenberg and Müller (1991). For exports where the ratio A of the country's export unit value to the average EU import unit value is above 1.15 , the quality is considered to be high; the quality is medium if $0.85 \leq \mathrm{A} \leq$ 1.15 , and is low if $\mathrm{A}<0.85$.

In 2000 only Estonia, Hungary and Slovenia had a higher share of high-quality exports than Portugal. The general picture is that medium quality exports predominate in Portugal (45.5\% of the total in 2000) whilst in the CEE countries (other than Bulgaria) the low quality range predominates. Thus, it may be the case that even in sectors in which Portugal is losing market share it is competing successfully with the CEEC in terms of quality. However this advantage could be eroded since all CEE countries other than Latvia and Slovenia improved the price-quality of their exports between 1993 and 2000 while the share of each category in total Portuguese exports remained fairly stable. 
The market-share analysis has shown that the growing penetration of CEE exports in the EU market has occurred mainly in medium and high technology sectors in which demand is dynamic and whose competitiveness depends largely on product differentiation and R\&D. These are precisely the sectors in which Portugal fared worst in terms of EU market share. The role of FDI is relevant in explaining this evolution, in that FDI is largely responsible for the transformation of the comparative advantage of CEE countries. Multinational firms attracted to CEE countries began to export to the EU. Export-oriented FDI, furthermore, is more important in dynamic high value-added sectors, and has thus contributed to the increasing specialisation of the CEEC in these sectors. ${ }^{9}$

It is very likely that the trade adjustment process is not yet complete, particularly in labour-intensive sectors where liberalisation was slower. For Portugal this may mean a further diminution in the traditional sectors. On the other hand however, it is also likely that the CEEC position in the more dynamic modern sectors will improve further. This may make it more difficult for Portugal to replace its traditional sectors by more dynamic ones, as illustrated in Table 1. These difficulties will be accentuated if FDI is displaced, which is the topic to which we now turn.

\section{Inward FDI - Competition between Portugal and CEEC?}

Inward FDI can be of considerable importance for peripheral countries seeking to converge on the more developed EU core. FDI impacts on a range of important areas: capital formation, employment creation, tax revenue generation and trade. FDI also has a number of indirect effects, involving the accumulation of technology, knowledge, skills and other resources representing the intangible assets of multinational firms (Blömstrom et al., 2000). The competitive pressures it introduces can also act as a stimulus to greater efficiency on the part of domestic firms. FDI is therefore likely to increase productivity

\footnotetext{
${ }^{9}$ It is nevertheless important to note the limitations of RCA analyses in this regard, as they present a static picture of a process that is in dynamic mutation; Barry and Hannan (2003b).
} 
and promote economic growth. This effect was confirmed for the Portuguese economy by Flôres et al. (2002) and Proença et al. (2002).

There has been a spectacular increase in CEE-bound FDI over the last decade, as shown in Table 11. But there are several reasons to assume that this trend will receive a further stimulus after adhesion. Firstly, the fact that efforts to remove any remaining nontariff barriers are likely to be pursued more vigorously in the case of intra-EU trade. Secondly, accession will increase the confidence of foreign investors by allowing the possibility of appeal beyond the courts of the associated countries to those of the European Union in the event of legal disputes arising. Thirdly, EU membership serves as some guarantee of transparency in the legal and business environment because of the acquis communautaire and the culture of checking the probity of Structural Funds expenditures and fourthly, entry to the Single Market will fully remove customs frontiers and trade barriers associated with different technical standards, and will allow full access to government procurement contracts throughout the EU. For all these reasons accession is likely to represent as dramatic a change in the CEE climate for foreign investors as it did for Ireland, Spain and Portugal upon their respective accessions to the EU (Barry, 2003).

Table 11 : FDI inward stock (in millions of current US dollars)

\begin{tabular}{|l|r|r|r|r|r|r|}
\hline & \multicolumn{2}{|c|}{1990} & \multicolumn{2}{|c|}{1995} & \multicolumn{2}{|c|}{2000} \\
\hline European Union & $\mathbf{7 3 9 . 5 6 1}$ & $\mathbf{( 1 0 0 )}$ & $\mathbf{1 . 1 3 1 . 4 2 7}$ & $\mathbf{( 1 5 3 )}$ & $\mathbf{2 . 3 7 6 . 2 4 4}$ & $\mathbf{( 3 2 1 , 3 )}$ \\
& 10.571 & $(100)$ & 18.381 & $(173.9)$ & 26.560 & $(251.3)$ \\
Sortugal & 65.916 & $(100)$ & 130.657 & $(198.2)$ & 142.420 & $(216.1)$ \\
Greece & 14.016 & $(100)$ & 19.306 & $(137.7)$ & 23.107 & $(164.9)$ \\
Ireland & 5.502 & $(100)$ & 11.706 & $(212.8)$ & 59.351 & $(1078.7)$ \\
& & & & & & \\
Total CEE & $\mathbf{3 . 6 6 2}$ & $\mathbf{( 1 0 0 )}$ & $\mathbf{3 1 . 4 6 8}$ & $\mathbf{( 8 5 9 . 3 )}$ & $\mathbf{1 0 2 . 2 8 8}$ & $\mathbf{( 2 7 9 3 . 2 )}$ \\
& & & & & & \\
Slovenia & 666 & $(100)$ & 1.763 & $(264.7)$ & 2.865 & $(430.2)$ \\
Bulgaria & 108 & $(100)$ & 445 & $(412.0)$ & 3.404 & $(3151.9)$ \\
C. Republic & 1.363 & $(100)$ & 7.350 & $(539.3)$ & 21.095 & $(1547.7)$ \\
Estonia & & & 674 & $(100)$ & 2.840 & $(421.4)$ \\
Hungary & 569 & $(100)$ & 10.007 & $(1758.7)$ & 19.863 & $(3490.9)$ \\
Latvia & & & 616 & $(100)$ & 2.081 & $(337.8)$ \\
Lithuania & 109 & $(100)$ & 7.843 & $(7195.4)$ & 36.475 & $(33463.3)$ \\
Poland & 766 & $(100)$ & 1.150 & $(150.1)$ & 6.439 & $(840.6)$ \\
Romania & 81 & $(100)$ & 1.268 & $(1565.4)$ & 4.892 & $(6039.5)$ \\
Slovakia & & & & & & \\
\hline
\end{tabular}

Source: World Investment Report (2001) 
In the case of Portugal, FDI inflows increased significantly after EU accession, reaching a peak of nearly 5\% of GDP in 1991. Between 1991 and 1994 there was a decrease, but after that period of time the increase in FDI inflows was resumed.

From 1996 onwards however, significant divestment flows have been registered, with an increasing tendency at least until 2000. ${ }^{10}$ In 1999, foreign direct investment net of divestment was only $1 \%$ of GDP and was actually negative in terms of firms' equity. Manufacturing industry, furthermore, received a declining share of FDI; while in 1994 this sector captured $45.8 \%$ of total FDI, in 2000 the percentage decreased to only $1.9 \% .^{11}$ FDI in Portugal goes primarily to the property sector and to other services, mainly financial. This is in contrast to the situation in the CEE countries and some of the other Cohesion countries. For example, manufacturing's share of FDI inflows averaged around $40 \%$ in Hungary and Poland and $30 \%$ in the Czech Republic.

Some recent evidence on the diversion of FDI flows away from Southern Europe to the CEE countries is provided by Braconier and Ekholm (2001), who analyse a firmlevel dataset on the operations of Swedish multinational companies. They show that the expansion in affiliate-firm employment in CEE countries, which totalled 15,000 over the period 1990 to 1998, came at the expense of affiliate activity in Southern Europe where employment fell by 14,000 over the same period.

A fact that may counteract this possible FDI diversion effect is that an increasing part of FDI comes from the neighbouring Spanish economy. In terms of FDI stock, in 2000 , Spain was the main investor, with $14.5 \%$ of total (in 1995, Spain occupied the third place, after France and UK), followed by the UK and France (12.9\% and $11.8 \%$, respectively). Between 1995 and 2000, Germany and UK slightly decreased their share in total FDI stock and, in the case of France, the reduction was greater, at around 5 percentage points. This evolution is consistent with the idea that geographic proximity influences the location of FDI.

Analysis of the threat that CEEC represent as competitors for foreign investment cannot, however, be confined to an extrapolation of recent flows. As mentioned earlier,

\footnotetext{
${ }^{10}$ Texas Instrument, Renault, Ford, Nestlé, Siemens, among others are examples of foreign firms that divested by the end of the 1990's.
} 
foreign investors are unlikely to see free trade as equivalent to EU membership and after adhesion the advantages of the CEE countries will increase. Thus, it seems more relevant to conduct a comparative evaluation of the competitive position of CEEC, Portugal and the remaining Cohesion countries in terms of the relevant factors for the attraction of FDI. This is the purpose of the remainder of this section, which uses information supplied by the Institute for Management Development (IMD). This source provides a wide range of data up to the year 2002.

In its annual report, IMD assesses 49 countries in terms of factors relevant to this aspect of competitiveness. In what follows we discuss the most relevant of these. All the evaluations are presented in a scale from 0 (representing the worst competitive position) to 10 (representing the best), with some exceptions. Our purpose is mainly to evaluate the relative position for each indicator for Portugal, the other EU Cohesion countries and the most relevant CEE countries (Hungary, the Czech Republic and Poland). Table 12 presents a first group of competitiveness indicators concerning government efficiency.

${ }^{11}$ In terms of stock, manufacturing industry represents $19.6 \%$ of total FDI (Leite et al., 2001). 
Table 12: Competitiveness factors -government efficiency (2002)

\begin{tabular}{|c|c|c|c|c|c|c|c|}
\hline Criterion: & Portugal & Spain & Greece & Ireland & Hungary & C. Rep. & Poland \\
\hline $\begin{array}{l}\text { [1] The legal framework is not } \\
\text { detrimental to competitiveness }\end{array}$ & $\begin{array}{l}3.53 \\
(42)\end{array}$ & $\begin{array}{l}5.85 \\
(24)\end{array}$ & $\begin{array}{l}4.09 \\
(37)\end{array}$ & $\begin{array}{l}6.91 \\
(12)\end{array}$ & $\begin{array}{l}5.93 \\
(23)\end{array}$ & $\begin{array}{l}4.25 \\
(34)\end{array}$ & $\begin{array}{l}2.91 \\
(46)\end{array}$ \\
\hline $\begin{array}{l}\text { [2] Real corporate taxes do not } \\
\text { discourage } \\
\begin{array}{ll}\text { activity } & \text { entrepreneurial } \\
\end{array}\end{array}$ & $\begin{array}{l}3.94 \\
(39)\end{array}$ & $\begin{array}{l}5.73 \\
(19)\end{array}$ & $\begin{array}{l}4.38 \\
(33)\end{array}$ & $\begin{array}{r}7.96 \\
(2)\end{array}$ & $\begin{array}{r}6.59 \\
(9)\end{array}$ & $\begin{array}{l}4.50 \\
(32)\end{array}$ & $\begin{array}{l}2.96 \\
(48)\end{array}$ \\
\hline $\begin{array}{l}\text { [3] Economic policies adapt } \\
\text { quickly to changes in the } \\
\text { economy }\end{array}$ & $\begin{array}{l}2.85 \\
(45)\end{array}$ & $\begin{array}{l}5.64 \\
(12)\end{array}$ & $\begin{array}{l}4.00 \\
(38)\end{array}$ & $\begin{array}{r}6.53 \\
(4)\end{array}$ & $\begin{array}{l}5.56 \\
(13)\end{array}$ & $\begin{array}{l}4.67 \\
(25)\end{array}$ & $\begin{array}{l}3.13 \\
(42)\end{array}$ \\
\hline $\begin{array}{l}\text { [4] Government decisions are } \\
\text { effectively implemented }\end{array}$ & $\begin{array}{l}2.70 \\
(46)\end{array}$ & $\begin{array}{l}5.58 \\
(15)\end{array}$ & $\begin{array}{l}3.16 \\
(40)\end{array}$ & $\begin{array}{r}6.32 \\
(8)\end{array}$ & $\begin{array}{l}5.56 \\
(16)\end{array}$ & $\begin{array}{l}4.67 \\
(26)\end{array}$ & $\begin{array}{l}3.03 \\
(44)\end{array}$ \\
\hline $\begin{array}{l}\text { [5] Transparency of government } \\
\text { policy }\end{array}$ & $\begin{array}{l}3.07 \\
(46)\end{array}$ & $\begin{array}{l}5.94 \\
(18)\end{array}$ & $\begin{array}{l}3.81 \\
(38)\end{array}$ & $\begin{array}{l}6.19 \\
(15)\end{array}$ & $\begin{array}{l}3.41 \\
(43)\end{array}$ & $\begin{array}{l}4.40 \\
(32)\end{array}$ & $\begin{array}{l}3.20 \\
(45)\end{array}$ \\
\hline $\begin{array}{l}\text { [6] Bureaucracy does not hinder } \\
\text { business activity }\end{array}$ & $\begin{array}{l}1.69 \\
(44)\end{array}$ & $\begin{array}{l}3.82 \\
(21)\end{array}$ & $\begin{array}{l}1.91 \\
(42)\end{array}$ & $\begin{array}{r}5.32 \\
(8) \\
\end{array}$ & $\begin{array}{l}3.63 \\
(23)\end{array}$ & $\begin{array}{l}3.00 \\
(26)\end{array}$ & $\begin{array}{l}1.26 \\
(48) \\
\end{array}$ \\
\hline $\begin{array}{l}\text { [7] Personal security and private } \\
\text { property are adequately protected }\end{array}$ & $\begin{array}{l}6.48 \\
(23)\end{array}$ & $\begin{array}{l}6.33 \\
(26)\end{array}$ & $\begin{array}{l}6.70 \\
(20)\end{array}$ & $\begin{array}{l}7.37 \\
(18)\end{array}$ & $\begin{array}{l}5.70 \\
(32)\end{array}$ & $\begin{array}{l}5.67 \\
(33)\end{array}$ & $\begin{array}{l}2.86 \\
(42)\end{array}$ \\
\hline $\begin{array}{l}\text { [8] Foreign companies are not } \\
\text { discriminated against by domestic } \\
\text { legislation }\end{array}$ & $\begin{array}{l}8.44 \\
(16)\end{array}$ & $\begin{array}{l}8.18 \\
(23)\end{array}$ & $\begin{array}{l}7.84 \\
(28)\end{array}$ & $\begin{array}{r}9.37 \\
(3)\end{array}$ & $\begin{array}{l}7.93 \\
(27)\end{array}$ & $\begin{array}{l}8.28 \\
(19)\end{array}$ & $\begin{array}{l}6.88 \\
(44)\end{array}$ \\
\hline $\begin{array}{l}\text { [9] Labour regulations are } \\
\text { flexible enough }\end{array}$ & $\begin{array}{l}2.50 \\
(47)\end{array}$ & $\begin{array}{l}3.82 \\
(33)\end{array}$ & $\begin{array}{l}3.81 \\
(34)\end{array}$ & $\begin{array}{l}6.04 \\
(12)\end{array}$ & $\begin{array}{r}7.19 \\
(6) \\
\end{array}$ & $\begin{array}{l}5.44 \\
(16)\end{array}$ & $\begin{array}{l}2.52 \\
(45) \\
\end{array}$ \\
\hline $\begin{array}{l}\text { [10] Access to local capital } \\
\text { markets is not restricted for } \\
\text { foreign firms }\end{array}$ & $\begin{array}{l}8.85 \\
(12)\end{array}$ & $\begin{array}{l}8.38 \\
(26)\end{array}$ & $\begin{array}{l}8.63 \\
(20)\end{array}$ & $\begin{array}{l}9.05 \\
(10)\end{array}$ & $\begin{array}{l}8.52 \\
(21)\end{array}$ & $\begin{array}{l}8.72 \\
(17)\end{array}$ & $\begin{array}{l}6.68 \\
(43)\end{array}$ \\
\hline $\begin{array}{l}\text { [11] Investment incentives are } \\
\text { attractive to foreign investors }\end{array}$ & $\begin{array}{l}6.39 \\
(24)\end{array}$ & $\begin{array}{l}6.46 \\
(23)\end{array}$ & $\begin{array}{l}5.02 \\
(36)\end{array}$ & $\begin{array}{r}8.60 \\
(2)\end{array}$ & $\begin{array}{r}7.56 \\
(8)\end{array}$ & $\begin{array}{r}8.83 \\
(1)\end{array}$ & $\begin{array}{l}4.60 \\
(40)\end{array}$ \\
\hline $\begin{array}{llr}\text { [12] Venture } & \text { capital is easily } \\
\text { available } & \text { for } & \text { business } \\
\text { development } & & \\
\end{array}$ & $\begin{array}{l}4.58 \\
(28)\end{array}$ & $\begin{array}{l}4.89 \\
(22)\end{array}$ & $\begin{array}{l}4.63 \\
(26)\end{array}$ & $\begin{array}{r}6.67 \\
(5)\end{array}$ & $\begin{array}{l}3.48 \\
(35)\end{array}$ & $\begin{array}{l}3.17 \\
(40)\end{array}$ & $\begin{array}{l}3.42 \\
(37)\end{array}$ \\
\hline $\begin{array}{l}\text { [13] Banking services are widely } \\
\text { developed }\end{array}$ & $\begin{array}{l}7.92 \\
(26) \\
\end{array}$ & $\begin{array}{l}8.03 \\
(25)\end{array}$ & $\begin{array}{l}7.03 \\
(33) \\
\end{array}$ & $\begin{array}{l}8.07 \\
(24) \\
\end{array}$ & $\begin{array}{l}7.11 \\
(32)\end{array}$ & $\begin{array}{l}5.89 \\
(41)\end{array}$ & $\begin{array}{l}6.38 \\
(37) \\
\end{array}$ \\
\hline $\begin{array}{l}\text { [14] Stock markets provide } \\
\text { adequate financing to firms }\end{array}$ & $\begin{array}{l}4.25 \\
(34)\end{array}$ & $\begin{array}{l}6.25 \\
(17)\end{array}$ & $\begin{array}{l}5.72 \\
(24)\end{array}$ & $\begin{array}{l}6.04 \\
(22)\end{array}$ & $\begin{array}{l}3.63 \\
(41)\end{array}$ & $\begin{array}{l}2.17 \\
(46)\end{array}$ & $\begin{array}{l}3.97 \\
(37)\end{array}$ \\
\hline $\begin{array}{l}\text { [15] Image abroad supports the } \\
\text { development of business }\end{array}$ & $\begin{array}{l}4.78 \\
(34)\end{array}$ & $\begin{array}{l}6.39 \\
(21) \\
\end{array}$ & $\begin{array}{l}4.44 \\
(37)\end{array}$ & $\begin{array}{r}8.32 \\
(3)\end{array}$ & $\begin{array}{l}6.67 \\
(19)\end{array}$ & $\begin{array}{l}6.25 \\
(23)\end{array}$ & $\begin{array}{l}3.82 \\
(39)\end{array}$ \\
\hline
\end{tabular}

Note: Values between brackets represent the country ranking in a total of 49 countries

Source: IMD

As one could expect, Ireland is by far the country best positioned across most criteria. Several weaknesses are evident in the Portuguese position relative to the CEEC. First, the justice system, a key element for the regular functioning of a market economy and for generation trust among investors, appears to be deficient. Other weaknesses appear at the level of government action: an uncompetitive fiscal system, a weak response to entrepreneurial needs and excessive bureaucracy are patent in Table 12 . 
Another relevant aspect is the excessive rigidity of labour markets. ${ }^{12}$ In what concerns the existence of venture capital and the functioning of banking services, the Portuguese situation is reasonable. Concerning the CEEC, two aspects should be pointed out: first, the strong position in particular of Hungary and the Czech Republic in the generality of the criteria considered, and second, their strong position with respect to criterion 11, reflecting the enormous effort made by these countries to attract FDI. ${ }^{13}$

Table 13 displays information concerning infrastructure.

\footnotetext{
${ }^{12}$ New labour legislation to allow greater flexibility is to be implemented in Portugal.

${ }^{13}$ Leite et al. (2001) also use this indicator but they take into consideration the average of the last 6 years. In their analysis, which includes the same countries as we do, the Czech Republic scores lowest, while Portugal is surpassed only by Ireland. The comparison with the present study reveals the rapid progress made by the CEEC in recent years.
} 
Table 13: Competitiveness factors - basic, technological, health and environment infrastructures (2002)

\begin{tabular}{|c|c|c|c|c|c|c|c|}
\hline Criterion & Portugal & Spain & Greece & Ireland & Hungary & C. Rep. & Poland \\
\hline $\begin{array}{l}\text { [1] Maintenance and development } \\
\text { of infrastructure is adequately } \\
\text { planned and financed }\end{array}$ & $\begin{array}{l}4.97 \\
(28)\end{array}$ & $\begin{array}{l}6.12 \\
(18)\end{array}$ & $\begin{array}{r}4.81 \\
(30)\end{array}$ & $\begin{array}{l}4.32 \\
(31)\end{array}$ & $\begin{array}{r}4.22 \\
(32)\end{array}$ & $\begin{array}{l}4.97 \\
(28)\end{array}$ & $\begin{array}{l}2.65 \\
(45)\end{array}$ \\
\hline $\begin{array}{l}\text { [2] Quality of air transportation is } \\
\text { adequate and efficient }\end{array}$ & $\begin{array}{l}6.82 \\
(27)\end{array}$ & $\begin{array}{l}6.48 \\
(31) \\
\end{array}$ & $\begin{array}{l}6.13 \\
(35) \\
\end{array}$ & $\begin{array}{l}5.75 \\
(39)\end{array}$ & $\begin{array}{l}5.93 \\
(38) \\
\end{array}$ & $\begin{array}{l}7.00 \\
(23)\end{array}$ & $\begin{array}{l}4.55 \\
(45) \\
\end{array}$ \\
\hline $\begin{array}{l}\text { [3] The distribution infrastructure } \\
\text { of goods and services is efficient }\end{array}$ & $\begin{array}{l}6.03 \\
(28) \\
\end{array}$ & $\begin{array}{l}6.15 \\
(26) \\
\end{array}$ & $\begin{array}{l}5.05 \\
(35) \\
\end{array}$ & $\begin{array}{l}3.54 \\
(46) \\
\end{array}$ & $\begin{array}{r}4.89 \\
(36) \\
\end{array}$ & $\begin{array}{l}5.67 \\
(30) \\
\end{array}$ & $\begin{array}{l}3.68 \\
(43) \\
\end{array}$ \\
\hline $\begin{array}{l}\text { [4] Energy infrastructure is } \\
\text { adequate and efficient }\end{array}$ & $\begin{array}{l}6.28 \\
(30)\end{array}$ & $\begin{array}{l}5.18 \\
(38)\end{array}$ & $\begin{array}{l}5.41 \\
(36)\end{array}$ & $\begin{array}{l}5.86 \\
(33)\end{array}$ & $\begin{array}{l}6.69 \\
(26)\end{array}$ & $\begin{array}{l}7.94 \\
(15)\end{array}$ & $\begin{array}{l}5.57 \\
(35)\end{array}$ \\
\hline $\begin{array}{l}\text { [5] Adequacy of communications } \\
\text { (availability, reliability, cost) }\end{array}$ & $\begin{array}{l}6.47 \\
(34)\end{array}$ & $\begin{array}{l}6.06 \\
(38)\end{array}$ & $\begin{array}{l}6.53 \\
(32)\end{array}$ & $\begin{array}{l}6.48 \\
(33)\end{array}$ & $\begin{array}{l}7.19 \\
(26)\end{array}$ & $\begin{array}{l}7.17 \\
(27)\end{array}$ & $\begin{array}{l}4.93 \\
(47)\end{array}$ \\
\hline $\begin{array}{l}\text { [6] New information technology } \\
\text { and its implementation meet } \\
\text { business requirements }\end{array}$ & $\begin{array}{l}6.64 \\
(33)\end{array}$ & $\begin{array}{l}5.76 \\
(45)\end{array}$ & $\begin{array}{l}6.13 \\
(42)\end{array}$ & $\begin{array}{l}6.49 \\
(36)\end{array}$ & $\begin{array}{l}6.81 \\
(30)\end{array}$ & $\begin{array}{l}7.14 \\
(27)\end{array}$ & $\begin{array}{l}4.70 \\
(49)\end{array}$ \\
\hline $\begin{array}{l}\text { [7] Suitable internet access } \\
\text { (availability, speed, cost) is } \\
\text { provided }\end{array}$ & $\begin{array}{l}6.92 \\
(34)\end{array}$ & $\begin{array}{l}6.09 \\
(44)\end{array}$ & $\begin{array}{l}6.59 \\
(36)\end{array}$ & $\begin{array}{l}6.00 \\
(46)\end{array}$ & $\begin{array}{l}6.07 \\
(45)\end{array}$ & $\begin{array}{l}6.94 \\
(31)\end{array}$ & $\begin{array}{l}4.16 \\
(49)\end{array}$ \\
\hline $\begin{array}{l}\text { [8] Fixed telephone lines-number } \\
\text { of main lines per } 1000 \\
\text { inhabitants* }\end{array}$ & $\begin{array}{l}441 \\
(28)\end{array}$ & $\begin{array}{l}460 \\
(26)\end{array}$ & $\begin{array}{l}578 \\
(17)\end{array}$ & $\begin{array}{l}503 \\
(22)\end{array}$ & $\begin{array}{l}368 \\
(32)\end{array}$ & $\begin{array}{r}378 \\
(30)\end{array}$ & $\begin{array}{l}296 \\
(34)\end{array}$ \\
\hline $\begin{array}{l}\text { [9] Mobile telephone-number of } \\
\text { subscribers per } 1000 \text { inhabitants* }\end{array}$ & $\begin{array}{r}823.1 \\
(7)\end{array}$ & $\begin{array}{r}731.4 \\
(14)\end{array}$ & $\begin{array}{r}729.3 \\
(17)\end{array}$ & $\begin{array}{r}753.5 \\
(12)\end{array}$ & $\begin{array}{r}484.5 \\
(28)\end{array}$ & $\begin{array}{r}676.4 \\
(21)\end{array}$ & $\begin{array}{r}258.6 \\
(35)\end{array}$ \\
\hline $\begin{array}{l}\text { [10] Number of computers per } \\
1000 \text { people* }\end{array}$ & $\begin{array}{r}178 \\
(31) \\
\end{array}$ & $\begin{array}{r}231 \\
(27) \\
\end{array}$ & $\begin{array}{r}112 \\
(35) \\
\end{array}$ & $\begin{array}{r}461 \\
(14)\end{array}$ & $\begin{array}{r}176 \\
(32) \\
\end{array}$ & $\begin{array}{r}179 \\
(30) \\
\end{array}$ & $\begin{array}{r}122 \\
(34) \\
\end{array}$ \\
\hline $\begin{array}{l}\text { [11] Number of internet users per } \\
1000 \text { people* }\end{array}$ & $\begin{array}{r}190 \\
(31) \\
\end{array}$ & $\begin{array}{r}199.3 \\
(29) \\
\end{array}$ & $\begin{array}{r}155.5 \\
(34)\end{array}$ & $\begin{array}{r}289.5 \\
(24) \\
\end{array}$ & $\begin{array}{r}168.8 \\
(33) \\
\end{array}$ & $\begin{array}{r}198.3 \\
(30) \\
\end{array}$ & $\begin{array}{r}125.5 \\
(35) \\
\end{array}$ \\
\hline $\begin{array}{l}\text { [12] Health infrastructure meets } \\
\text { the needs of society }\end{array}$ & $\begin{array}{l}3.53 \\
(39) \\
\end{array}$ & $\begin{array}{l}7.15 \\
(13) \\
\end{array}$ & $\begin{array}{l}4.00 \\
(35) \\
\end{array}$ & $\begin{array}{l}4.63 \\
(30) \\
\end{array}$ & $\begin{array}{l}2.15 \\
(47) \\
\end{array}$ & $\begin{array}{l}6.50 \\
(22) \\
\end{array}$ & $\begin{array}{l}2.38 \\
(46) \\
\end{array}$ \\
\hline $\begin{array}{l}\text { [13] Environmental laws and } \\
\text { compliance do not hinder the } \\
\text { competitiveness of business }\end{array}$ & $\begin{array}{l}6.11 \\
(24)\end{array}$ & $\begin{array}{l}6.48 \\
(17)\end{array}$ & $\begin{array}{l}5.72 \\
(32)\end{array}$ & $\begin{array}{l}6.56 \\
(14)\end{array}$ & $\begin{array}{l}6.52 \\
(16)\end{array}$ & $\begin{array}{l}5.61 \\
(35)\end{array}$ & $\begin{array}{l}4.41 \\
(48)\end{array}$ \\
\hline [14] Quality of life & $\begin{array}{l}6.00 \\
(29) \\
\end{array}$ & $\begin{array}{l}8.58 \\
(15)\end{array}$ & $\begin{array}{l}6.50 \\
(24) \\
\end{array}$ & $\begin{array}{l}7.93 \\
(19) \\
\end{array}$ & $\begin{array}{l}5.19 \\
(35) \\
\end{array}$ & $\begin{array}{l}6.33 \\
(25) \\
\end{array}$ & $\begin{array}{l}3.51 \\
(44)\end{array}$ \\
\hline $\begin{array}{l}\text { [15] National culture is open to } \\
\text { foreign ideas }\end{array}$ & $\begin{array}{l}8.00 \\
(11)\end{array}$ & $\begin{array}{l}6.85 \\
(34)\end{array}$ & $\begin{array}{l}7.25 \\
(25)\end{array}$ & $\begin{array}{l}7.65 \\
(19)\end{array}$ & $\begin{array}{l}6.89 \\
(32)\end{array}$ & $\begin{array}{l}6.61 \\
(38)\end{array}$ & $\begin{array}{l}5.85 \\
(45)\end{array}$ \\
\hline $\begin{array}{l}\text { [16] Values of the society support } \\
\text { competitiveness }\end{array}$ & $\begin{array}{l}5.64 \\
(39) \\
\end{array}$ & $\begin{array}{l}5.76 \\
(35) \\
\end{array}$ & $\begin{array}{l}5.88 \\
(33) \\
\end{array}$ & $\begin{array}{l}7.54 \\
(10) \\
\end{array}$ & $\begin{array}{l}6.59 \\
(25) \\
\end{array}$ & $\begin{array}{l}5.72 \\
(37) \\
\end{array}$ & $\begin{array}{l}4.61 \\
(46) \\
\end{array}$ \\
\hline $\begin{array}{l}\text { [17] Office rent - total occupation } \\
\text { cost (US\$/Sq. M. per year)* }\end{array}$ & $\begin{array}{r}302 \\
(21) \\
\end{array}$ & $\begin{array}{l}461 \\
(38) \\
\end{array}$ & $\begin{array}{l}438 \\
(33) \\
\end{array}$ & $\begin{array}{r}568 \\
(44) \\
\end{array}$ & $\begin{array}{r}254 \\
(15) \\
\end{array}$ & $\begin{array}{r}284 \\
(19) \\
\end{array}$ & $\begin{array}{r}413 \\
(31) \\
\end{array}$ \\
\hline
\end{tabular}

Note: Values between brackets represent the country ranking in a total of 49 countries

Source: IMD ; * - values in 2001

In this case, in contrast to the indicators related to government efficiency, the Portuguese position is not dramatically different from that of the CEEC (once again with Hungary and the Czech Republic at the top position) or the other Cohesion countries. In 
fact, despite specific differences, we do not detect, in this group of indicators, a clear obstacle to the attraction of FDI in any of the countries considered.

The quality of human capital is generally agreed to be one of the major weaknesses of the Portuguese economy and so it deserves a more detailed study. Table 14 supplies information on this.

Table 14 : Competitiveness factors - human capital (education and science) -2002

\begin{tabular}{|c|c|c|c|c|c|c|c|}
\hline Criterion & Portugal & Spain & Greece & Ireland & Hungary & C. Rep. & Poland \\
\hline $\begin{array}{l}\text { [1] PISA results ( } 15 \text { years of } \\
\text { age)- reading literacy }-23 \\
\text { countries* }\end{array}$ & $\begin{array}{r}470 \\
(22)\end{array}$ & $\begin{array}{l}493 \\
(15)\end{array}$ & $\begin{array}{r}474 \\
(21)\end{array}$ & $\begin{array}{r}527 \\
(3)\end{array}$ & $\begin{array}{r}480 \\
(19)\end{array}$ & $\begin{array}{r}492 \\
(16)\end{array}$ & $\begin{array}{l}479 \\
(20)\end{array}$ \\
\hline $\begin{array}{l}\text { [2] PISA results (15 years of } \\
\text { age)- scientific literacy }-23 \\
\text { countries* }\end{array}$ & $\begin{array}{l}459 \\
(22)\end{array}$ & $\begin{array}{l}491 \\
(16)\end{array}$ & $\begin{array}{l}461 \\
(21)\end{array}$ & $\begin{array}{r}513 \\
(7)\end{array}$ & $\begin{array}{l}496 \\
(13)\end{array}$ & $\begin{array}{r}511 \\
(9)\end{array}$ & $\begin{array}{l}483 \\
(18)\end{array}$ \\
\hline $\begin{array}{l}\text { [3] PISA results ( } 15 \text { years of } \\
\text { age)- mathematical literacy- } 23 \\
\text { countries* }\end{array}$ & $\begin{array}{l}454 \\
(21)\end{array}$ & $\begin{array}{l}476 \\
(18)\end{array}$ & $\begin{array}{r}447 \\
(22)\end{array}$ & $\begin{array}{r}503 \\
(12)\end{array}$ & $\begin{array}{l}488 \\
(17)\end{array}$ & $\begin{array}{r}498 \\
(14)\end{array}$ & $\begin{array}{l}470 \\
(19)\end{array}$ \\
\hline $\begin{array}{l}\text { [4] Total public expenditure on } \\
\text { education - percentage of GDP }\end{array}$ & $\begin{array}{r}5.6 \\
(20)\end{array}$ & $\begin{array}{r}4.5 \\
(28)\end{array}$ & $\begin{array}{r}3.4 \\
(44)\end{array}$ & $\begin{array}{r}6.7 \\
(12)\end{array}$ & $\begin{array}{r}6.3 \\
(15)\end{array}$ & $\begin{array}{r}4.2 \\
(30)\end{array}$ & $\begin{array}{r}5.9 \\
(18)\end{array}$ \\
\hline $\begin{array}{l}\text { [5] The educational system meets } \\
\text { the needs of a competitive } \\
\text { economy }\end{array}$ & $\begin{array}{l}3.03 \\
(44)\end{array}$ & $\begin{array}{l}4.89 \\
(25)\end{array}$ & $\begin{array}{l}3.47 \\
(42)\end{array}$ & $\begin{array}{r}8.00 \\
(2)\end{array}$ & $\begin{array}{l}6.67 \\
(10)\end{array}$ & $\begin{array}{l}5.64 \\
(20)\end{array}$ & $\begin{array}{l}3.64 \\
(40)\end{array}$ \\
\hline $\begin{array}{l}\text { [6] University education meets } \\
\text { the needs of a competitive } \\
\text { economy }\end{array}$ & $\begin{array}{l}3.89 \\
(45)\end{array}$ & $\begin{array}{l}5.14 \\
(32)\end{array}$ & $\begin{array}{l}3.88 \\
(46)\end{array}$ & $\begin{array}{r}8.04 \\
(3)\end{array}$ & $\begin{array}{l}6.96 \\
(13)\end{array}$ & $\begin{array}{l}6.03 \\
(22)\end{array}$ & $\begin{array}{l}3.94 \\
(44)\end{array}$ \\
\hline [7] Economic literacy & $\begin{array}{l}3.53 \\
(42) \\
\end{array}$ & $\begin{array}{l}4.77 \\
(30)\end{array}$ & $\begin{array}{l}4.75 \\
(31)\end{array}$ & $\begin{array}{r}7.02 \\
(8) \\
\end{array}$ & $\begin{array}{l}5.78 \\
(22) \\
\end{array}$ & $\begin{array}{l}5.11 \\
(28)\end{array}$ & $\begin{array}{l}2.90 \\
(47) \\
\end{array}$ \\
\hline $\begin{array}{l}\text { [8] Qualified engineers are } \\
\text { available in labour market }\end{array}$ & $\begin{array}{l}5.53 \\
(42)\end{array}$ & $\begin{array}{l}6.95 \\
(26)\end{array}$ & $\begin{array}{l}7.09 \\
(25)\end{array}$ & $\begin{array}{l}7.29 \\
(22)\end{array}$ & $\begin{array}{r}8.30 \\
(4)\end{array}$ & $\begin{array}{l}7.67 \\
(16)\end{array}$ & $\begin{array}{l}6.63 \\
(30)\end{array}$ \\
\hline $\begin{array}{l}\text { [9] Knowledge transfer between } \\
\text { firms and universities }\end{array}$ & $\begin{array}{l}2.86 \\
(45)\end{array}$ & $\begin{array}{l}3.36 \\
(36)\end{array}$ & $\begin{array}{l}3.34 \\
(37)\end{array}$ & $\begin{array}{l}5.65 \\
(11)\end{array}$ & $\begin{array}{l}4.44 \\
(25)\end{array}$ & $\begin{array}{l}4.42 \\
(27)\end{array}$ & $\begin{array}{l}2.72 \\
(46)\end{array}$ \\
\hline $\begin{array}{l}\text { [10] Total expenditure on R\&D - } \\
\text { percentage of GDP }\end{array}$ & $\begin{array}{r}0.753 \\
(31)\end{array}$ & $\begin{array}{r}0.897 \\
(28)\end{array}$ & $\begin{array}{r}0.705 \\
(32)\end{array}$ & $\begin{array}{r}1.608 \\
(20)\end{array}$ & $\begin{array}{r}0.806 \\
(30)\end{array}$ & $\begin{array}{r}1.352 \\
(23)\end{array}$ & $\begin{array}{r}0.700 \\
(33)\end{array}$ \\
\hline $\begin{array}{l}\text { [11] Science in schools is } \\
\text { adequately taught }\end{array}$ & $\begin{array}{l}3.25 \\
(45) \\
\end{array}$ & $\begin{array}{l}4.58 \\
(32) \\
\end{array}$ & $\begin{array}{l}5.50 \\
(23) \\
\end{array}$ & $\begin{array}{l}5.09 \\
(25)\end{array}$ & $\begin{array}{r}7.00 \\
(3) \\
\end{array}$ & $\begin{array}{l}6.39 \\
(10) \\
\end{array}$ & $\begin{array}{l}3.79 \\
(40) \\
\end{array}$ \\
\hline $\begin{array}{l}\text { [12] Information technology skills } \\
\text { are readily available in labour } \\
\text { force }\end{array}$ & $\begin{array}{l}6.11 \\
(40)\end{array}$ & $\begin{array}{l}6.06 \\
(42)\end{array}$ & $\begin{array}{l}6.16 \\
(39)\end{array}$ & $\begin{array}{l}7.93 \\
(10)\end{array}$ & $\begin{array}{l}7.26 \\
(26)\end{array}$ & $\begin{array}{l}6.72 \\
(32)\end{array}$ & $\begin{array}{l}6.59 \\
(33)\end{array}$ \\
\hline $\begin{array}{l}\text { [13] Labour relations are } \\
\text { generally productive }\end{array}$ & $\begin{array}{l}5.53 \\
(33) \\
\end{array}$ & $\begin{array}{l}5.88 \\
(30)\end{array}$ & $\begin{array}{l}5.19 \\
(39)\end{array}$ & $\begin{array}{l}7.26 \\
(11)\end{array}$ & $\begin{array}{l}6.74 \\
(18)\end{array}$ & $\begin{array}{l}6.17 \\
(27) \\
\end{array}$ & $\begin{array}{l}4.76 \\
(43) \\
\end{array}$ \\
\hline [14] Worker motivation is high & $\begin{array}{l}4.53 \\
(40)\end{array}$ & $\begin{array}{l}5.42 \\
(32)\end{array}$ & $\begin{array}{l}4.44 \\
(42)\end{array}$ & $\begin{array}{r}7.16 \\
(8)\end{array}$ & $\begin{array}{l}5.85 \\
(25)\end{array}$ & $\begin{array}{l}5.56 \\
(30)\end{array}$ & $\begin{array}{l}3.71 \\
(46)\end{array}$ \\
\hline $\begin{array}{l}\text { [15] Skilled labour is available in } \\
\text { labour market }\end{array}$ & $\begin{array}{l}5.07 \\
(43) \\
\end{array}$ & $\begin{array}{l}6.33 \\
(36)\end{array}$ & $\begin{array}{l}6.03 \\
(39)\end{array}$ & $\begin{array}{l}7.05 \\
(26)\end{array}$ & $\begin{array}{l}7.11 \\
(23)\end{array}$ & $\begin{array}{l}7.33 \\
(18)\end{array}$ & $\begin{array}{l}6.38 \\
(34) \\
\end{array}$ \\
\hline
\end{tabular}

Note: Values between brackets represent the country ranking in a total of 49 countries

Source: IMD and OECD (2001); * - values in 2000. 
Here there is a wide gap between Portugal, Greece and Poland on the one hand, as against the other countries considered. The comparison between Portugal and the CEEC is particularly damning because the central problem for Portugal is not an input question (the expenditures with education and R\&D are at levels similar to those of the other countries) but because of the quality of the education and science systems, their connection with entrepreneurial activity and their capacity to satisfy the needs of a competitive economy. The low levels of literacy and the lack of skilled labour capable of fulfilling firms' needs represent weaknesses of the Portuguese economy and compromise the ability of the country to attract FDI mainly in the case of sectors with a higher technological component and skilled labour requirements.

Portugal has the lowest productivity levels in the EU15. This global picture in terms of human capital, together with a specialisation in sectors of low added value, labour intensity, facing declining demand and with a weak technological component (as emphasised in section 2), are decisive factors in explaining this.

The degree of centrality (or "closeness to purchasing power") also affects FDI in certain particular sectors. ${ }^{14}$ Schürmann and Talaat (2000) rank EU and CEE countries in this regard. Their index provides a measure of travel costs between points within the overall region weighted by the purchasing power that each point represents. The most peripheral regions at present are the Baltic states, Northern Sweden and Finland, Bulgaria and Romania. Hungary, Slovenia, the Czech and Slovak Republics and the Southwest of Poland are no more peripheral than Ireland, Spain or Portugal and are less peripheral than Greece.

The main weaknesses in Portugal can only be addressed over time. On the contrary, the CEEC, and in particular the Czech Republic and Hungary, not only have displayed rapid progress in some of these respects but they are on the way to correct the more relevant in their case, i.e. at the infrastructure level, particularly with the implementation of the huge TINA transport infrastructure plans for Central and Eastern Europe.

\footnotetext{
${ }^{14}$ In fact, only about one-fifth of foreign investment is allocated to industries where low labour costs play a significant role and where the share of unskilled labour is relatively high (Brücker,2001).
} 
Portuguese disadvantage can be illustrated with reference to the 2002 report of the international consultancy AT Kearney. AT Kearney makes an annual inquiry into the planned foreign investment decisions of the 1000 largest firms in the world. In the 2002 report, which puts China and the US at the top of the table, Portugal is, as in the last 5 years, not included in the first 25 countries. This report points out three explanations for the Portuguese situation. First, large world firms' managers put great emphasis on the budgetary and monetary policies of the different countries. The recent evolution of the Portuguese deficit, reaching 4.1\% of GDP in 2001, weakened Portugal's image within the euro zone (though it was reduced to less than $3 \%$ by the end of 2002). A second factor is related to FDI origin. Propensity to invest is at present higher in USA and Japan but FDI inflows in Portugal are mainly of European origin. The third problem is competition from the CEEC. In fact, by contrast to the Portuguese position, the three main CEE countries that host FDI are all well positioned in the ranking of AT Kearney.

As against this, however, it is important to note that each previous tradeliberalisation episode within Europe increased the pool of FDI both from within Europe and from outside (Dunning, 1997a, b). The goods produced by multinational firms also tend to have relatively high income elasticities of demand so that the expected growth in the CEEC10 consequent on enlargement should generate further flows of FDI into and within the newly expanded EU (Barry and Hannan, 2003a). A further relevant detail is that the Single Market liberalisation was associated with an expansion in the average number of plants that the leading multinational firms in the EU maintained. Among such firms with plants in Portugal for example, the average number of EU countries (other than their home bases) in which they maintained plants rose from 4.4 in 1987 to 5 in 1993, while the share of their European foreign production that they located in Portugal increased by 8 percent (Pavelin and Barry, 2003). This suggests that the development of the Single Market was associated with a further fragmentation of the production chain. If this proves to be the case it will be efficiency-enhancing and should operate to the further benefit of Portugal's foreign-owned industry.

The notion that enlargement will considerably enhance the attractiveness of the CEE countries as a location for export-oriented foreign direct investment, and as such will allow them to compete more strongly and successfully for such investment, will also 
stimulate Portuguese firms to invest in these countries. While Portugal has recently become a net investor abroad and Portuguese investment in CEE markets is increasing, it remains slight, with a weight of no more than $1 \%$ of total Portuguese direct investment abroad. Poland is the main destination for these firms, with $98 \%$ of the total in the 199699 period. $^{15}$

\section{Migration Issues}

The possibility of substantial migration flows from CEE countries to the EU15 is a widely discussed issue because of the very large income gap that exists, as well as the geographical proximity of the accession countries. This has led EU incumbents to favour only a gradual opening up of labour markets, in the knowledge that ongoing convergence in living standards will make substantial migration less likely.

So far, migration flows from CEEC have been very modest, which is not surprising given the rigid immigration legislation in EU countries. At the end of the 1990 's, the stock of foreign residents who have immigrated from the CEEC-10 to the EU is estimated at some 870,000 individuals, accounting for around $0.5 \%$ of the total CEE population, $0.2 \%$ of the total EU population and $0.3 \%$ of the total EU workforce. The consensus is that, even with full liberalisation, such flows will not increase dramatically. The main reason is that economic convergence is likely over the medium term, while migration is hindered by high transaction costs and the limited absorption capacity of labour markets in the destination countries.

The experience of the previous southern enlargement of Greece, Portugal and Spain is usually taken as a benchmark. These acceding countries also displayed substantial differences in terms of incomes and wages (though more attenuated) and geographical proximity to EU incumbent countries, but the results were very modest. Some of these traditional EU emigration countries have even turned into immigration countries. According to Brücker (2001), the stock of foreign residents from the Southern

\footnotetext{
${ }^{15}$ Portuguese firms still prefer markets that are apparently less risky and more familiar, such as Brazil, Spain and the ex-colonies in Africa.
} 
EU members had already reached equilibrium levels when free movement was allowed (between 6 and 7 years after accession).

Estimates of likely migration patterns take into account income differences, distances and traditional ties between sending and receiving economies, the labourmarket characteristics and demographics of the various countries and expectations of future economic evolutions. Boeri and Brücker (2000) incorporate these various determinants, and, based on an assumed convergence of 2 percent per annum between CEEC and EU income levels and no significant change in unemployment rates, conclude that after full liberalisation a maximum of 350,000 immigrants will move in the first year with this figure declining to less than 150,000 a decade after. In the long term (2030) the population of CEEC living in the EU is expected to increase from the current $0.2 \%$ level to $1.1 \%$.

These potential flows, furthermore, will be concentrated in particular on Germany and Austria, which are at the end location for over 80 percent of CEE migrants at present.

Traditionally, Portugal has been characterised by emigration rather than immigration, and substantial immigration is not envisaged in most studies on enlargement. Boeri and Brücker (2000) predict the stock of CEE residents in Portugal to rise from a figure of 780 that they quote for 1998 to a total of 3,560 by 2030 . However, recently, there has been a significant inflow of migrants, including from Eastern countries, to occupy less skilled jobs in the construction sector (which registered a boom in the 1990's, in part supported by European Funds), and also in sectors such as restaurants and domestic services.

Portugal has also adopted what appeared to be a more permissive immigration legislation than a number of other EU countries. In 1992-93 and again in 1996, illegal immigrants were allowed to apply for a "residence permit". The result was the legalisation of around 70,000 individuals, and the prospect of a "friendly" policy towards immigration that largely contributed to new inflows in the late 1990's.

The Decree Law $n^{\circ} 4 / 2001$ aimed to counteract the facilities of the previous decade by creating the legal notion of "temporary stay permit" in addition to the "residence permit". This new status was conferred for one year to those with a work 
contract, with the possibility of being renewed for a maximum of five years. Only in the end of this period may foreigners apply for a "residence permit". The purpose of this law was to reduce expectations of a permanent legalisation and also to deter employment of illegal immigrants. It is highly expectable, however, that a significant proportion of this new legal segment of "temporary workers" acquire a more permanent resident status as shown by the experience of other European host countries that have adopted a similar policy decades ago ${ }^{16}$.

National statistics show that in 1980 there was only 50,750 legalised immigrants in Portugal ( 0.5 per cent of total Portuguese population), while by 1999 the total number of foreigners had increased almost fourfold to more than 190,000 (1.9 per cent of total population). Most of Eastern immigration is not included in these figures as just a few people from Eastern Europe were legally in Portugal in 1999. However, some estimates used by the Portuguese media report between 60,000 to 200,000 illegal immigrants in the turn of the decade, most of them probably from Eastern Europe (Rita, 2002). The Social Support to Eastern Immigrants Association in Portugal (ASIL) estimated for mid-2002 a figure of 300,000 immigrants from there, while an increase to around 500,000, mainly relatives of those already in residence, is expected by 2004 .

Most of these Eastern immigrants in Portugal come from Ukraine, followed at some distance by Moldovans, Romanians and Russians. Ukrainians already represent the third largest foreign community in Portugal, with over 40,000 "temporary stay permits" granted during the legalisation undertaken in 2001, i.e., $35.4 \%$ of the total (Peixoto, 2002). Entrance and stay of many of these immigrants is linked to trafficking networks, which contributes to speed up the process of migration.

Will Eastern immigration into Portugal increase substantially in the future? It may do, primarily because of low unemployment relatively to the EU average while the female participation rate is higher than the EU average (at $63 \%$ compared to $59 \%$ in 1999). However, there are a range of factors that make Portugal a less desirable location from the viewpoint of potential immigrants. Per capita income and wage levels are low, the geographical position is not favourable and there are no significant cultural affinities

\footnotetext{
${ }^{16}$ A new law, to start on March 2003, introduces more stringent rules for legal immigration, which will depend on a system of quotas, while those that in an illegal situation are enforced to leave the country.
} 
or historical linkages. Besides, the unemployment rate is rapidly increasing (from 3.9\% in the second quarter of 2001 to $5.1 \%$ in the third quarter of 2002). As unemployment primarily affects unskilled workers, this will make the job market less attractive.

Another relevant issue concerns the impact of immigration. The effect on the labour market and on per capita income will depend primarily on immigrant skill levels relative to the indigenous population. If skill levels are equivalent, then with international capital mobility the effects are minimal. If immigrants are less skilled, the distribution of income becomes less equitable as downward pressure is exerted on the unskilled wage. Unemployment may also rise, as it tends to be concentrated among the less skilled. The net fiscal costs of immigration will also be larger as unskilled immigrants use more government services and pay less tax. All these effects will be reversed of course if immigrants are more highly skilled than the indigenous population. But the situation in Portugal, as in the rest of the EU, is that most immigrants of Eastern European origin are in occupations which do not fully reflect their skills.

Requests during 2001 on "temporary stay permits" show the following distribution by sector of the Eastern European population: $43.6 \%$ in construction, $21.3 \%$ in manufacturing, $15.4 \%$ in services, $6.7 \%$ in trade, $6.5 \%$ in agriculture, fishing and extractive industries and $6.3 \%$ in hotels and restaurants (Pires, 2002).

A possible indirect impact of future free labour will be a crowding-out of Portuguese emigrants by migrants from the East. Such an effect would increase further the pressures on the Portuguese unskilled labour market. Almost 10 per cent of the Portuguese population are resident in other EU countries, predominantly in France and, to a lesser extent, in Germany. These two countries received between 1955 and 1996, respectively, over 1047,000 and 344,000 Portuguese emigrants (Peixoto, 1999). Outflows to France decreased in the period $1975-96$ (to $16 \%$ of the total registered in the period 1955-74), but emigration to Germany diminished only slightly between these two subperiods. Even if such a crowding-out effect were not to occur in an expressive way, Eastern migration may always discourage further outflows from Portugal into present EU members. 


\section{Economic and Social Cohesion Policy}

The coming enlargement will entail a substantial increase in demands upon the EU budget, notably in the cases of the CAP and the Structural Funds. It has been agreed however that the ceiling on the EU budget will remain at $1.27 \%$ of GDP.

Analyses carried out in advance of the agreement reached in Copenhagen in December 2002 were based on an assumed net cost of enlargement of around 20 billion euro per annum. On the basis of the current distribution of net income payments and receipts across EU member states Portugal's share of these costs would have come to around 342 million euro per annum (CEPR, 2002). As is well known however, the Copenhagen agreement represented a considerably better deal for incumbent EU members than had long been anticipated. Rather than the 20 billion euro per annum estimate of Baldwin et al. (1997) and CEPR (2002), gross enlargement costs are now likely to sum to 41 billion euro over the three years 2004-2006. With 15 billion to be covered by new member states' contributions this brings the net cost down to only 26 billion euro, or around 9 billion euro per annum. ${ }^{17}$ Again on the basis of the current distribution of net income payments and receipts Portugal's share of these costs would come to around 152 million euro per annum.

The cost to Portugal would escalate however if costs and benefits were to be redistributed within the EU in line with current income levels. It is well known that Germany bears a disproportionate share of the current burden while countries like France, Ireland and Greece, and to a far lesser extent Portugal, contribute less than the figures warranted by their current income levels. ${ }^{18}$ Over time it has to be envisaged that a more equitable sharing of the burden will be negotiated among EU member states. de la Fuente and Doménech (2001) calculate that Portugal is currently over-subsidised to the tune of 600 million euro per annum (compared to an Irish figure of around 2 billion

\footnotetext{
${ }^{17}$ The assessment of the European Enlargement Commissioner delivered to the parliament Foreign Affairs Committee on January 23 was that the likely inability of the accession countries to draw down all the funds available to them may reduce the net cost to as little as 10.3 billion euro over this three year period 20042006.

[http://europa.eu.int/comm/enlargement/docs/newsletter/latest_weekly.htm]
} 
euro!). Given that any scaling upwards of the budgetary costs of enlargement will raise the profile of this item on the EU agenda, there may be a more substantial change over time in the flow of funds between Portugal and the rest of the EU.

While it has been agreed that the budgetary funds assigned to each member state will not change during the period of validity of Agenda 2000 - i.e. until 2006 - due to the separation principle established in the Inter-institutional Agreement, the position is likely to change after that date. If the present criterion for Objective 1 eligibility is maintained, the Portuguese regions of Algarve and Madeira (as well as Lisboa e Vale do Tejo which have already lost that status) will no longer be eligible for Objective 1 status. ${ }^{19}$ Based on current information, the other Portuguese regions are unlikely to lose that status by 2007 , not is it likely that Portugal will lose its eligibility for cohesion funding. ${ }^{20}$

The Structural Funds - the European Regional Development Fund (ERDF), the European Social Fund (ESF), the European Agricultural Guidance and Guarantee Fund (EAGGF) and the Financial Instrument for Fisheries Guidance (FIFG) - and the Cohesion Funds (for environment and transport infrastructure projects in countries with a per capita income less than $90 \%$ of the EU average) - not only stimulate demand but also operate on the supply side by supporting investment in infrastructure and human capital and thus increasing productivity and competitiveness. Total EU transfers in the period 1989-1999 were most pronounced in the Cohesion countries. ${ }^{21}$ Community support accounted for almost 15 percent of total investment in Greece in the 1994-99 period, 14 percent in Portugal, 10 percent in Ireland and 7 percent in Spain.

How important have those funds been for the Portuguese economy? Table 15 summarises the impact of Structural Funds in terms of additional growth of GDP.

\footnotetext{
${ }^{18}$ Spain is found to contribute around one and a half billion euro per annum more than is warranted according to these calculations (de la Fuente and Doménech, 2001).

${ }^{19}$ The exclusion of Madeira from Objective 1 is probably related to its high weight of off-shore financial activities and does not reflect the structural reality of the region. Nevertheless, owing to the ultra-peripheral region statute there is the possibility of its retaining its Objective 1 status (Ministry of Economy, 2002).

${ }^{20}$ This will not be the case for Spain (Martín et al. , 2002).
} 
Table 15: Impact of Structural Funds (percentage addition to GDP)

\begin{tabular}{|l|r|r|r|r|r|r|r|r|r|}
\hline & \multicolumn{3}{|c|}{ Demand effects } & \multicolumn{3}{c|}{ Supply effects } & \multicolumn{3}{c|}{ Total effects } \\
\cline { 2 - 10 } & 1994 & 1999 & 2020 & 1994 & 1999 & 2020 & 1994 & 1999 & \multicolumn{1}{c|}{2020} \\
\hline Ireland & 6.2 & 5.9 & 4.0 & & 3.4 & 8.4 & 6.2 & 9.3 & 12.4 \\
\hline Greece & 1.1 & 4.8 & 1.5 & 0.1 & 4.6 & 8.0 & 1.2 & 9.4 & $9.5^{*}$ \\
\hline Spain & 1.9 & 2.9 & 1.9 & & 1.4 & 6.8 & 1.9 & 4.3 & 8.7 \\
\hline Portugal & 7.0 & 8.1 & 7.6 & & 1.1 & 1.3 & 7.0 & 9.2 & 8.9 \\
\hline
\end{tabular}

Source: European Commission (1999); * 2010

Structural Funds have played an important role in Portuguese growth and convergence. $^{22}$ In 1986, when Portugal adhered to EU, Portuguese per capita income corresponded to $55.1 \%$ of EU average. In 2000 , that value had increased to $75.3 \%$. However, it remains a long way from the EU average; the European Commission's Second Cohesion Report predicts that it will be at least 20-30 years before this can be attained. Furthermore, the expected convergence between Portuguese NUTS II regions did not occur, as divergence increased slightly in recent years (Porto, 2002).

The $75 \%$ per capita GDP threshold for Objective 1 eligibility may be revised upwards to ensure that regions currently eligible for assistance and whose need will continue beyond 2006 are not rendered ineligible. The crucial point however is how the additional effort required of an effective regional funding policy in the context of the enlarged Union is to be financed. One solution would be to increase the limit of the "own resources"; this limit was fixed at the Edinburgh Summit in 1992 and has not been changed since then. However, the net contributory countries will hardly accept this solution. The other - more realistic - solution, is related to the reform of the Common Agricultural Policy (CAP). CAP expenditure is by far the largest item in the Community's global budget - accounting for around $40 \%$ of EU expenditures - and exceeds regional development funding to a significant degree.

CAP reform is required not only because it is one of the main policies of the EU in budgetary terms, but also because of the size of the agriculture sector in many acceding countries. With enlargement the CAP becomes even more unsustainable,

\footnotetext{
${ }^{21}$ At present, Cohesion Fund covers one sixth of the EU population. After the enlargement, if the criterion for eligibility is maintained, that value will increase to one third of the EU population.

${ }^{22}$ Table 15 also reveals that Portugal relied more on demand expansion, via investment in physical infrastructures, whereas Ireland favoured investment in human capital, which - given how that policy was
} 
increasing the imperative to shift its focus away from funding production towards the funding of rural development. This would increase the resources available for regional development as other monies are freed up.

Portugal is one of the countries that benefits least from the CAP, receiving only $1.6 \%$ of total transfers. In fact, it is the only cohesion country that is a net contributor to CAP. The transfer of part of current CAP expenditures into regional funding - entailing abandoning the current limit of $0.46 \%$ of EU GDP for Structural Actions - would help maintain the level of structural support that Portugal receives at present.

\section{Conclusion}

Enlargement will have important implications for Portugal. To some extent these are already noticeable in the wake of the Europe Agreements. Portuguese exports bear a strong similarity to those from Central and Eastern Europe, and have been losing EU market share as the CEE economies expand. To this extent Portugal can be said to be "being squeezed from below" in that its traditional export sectors are under threat. At the same time, its specialisation has been increasingly confined to low-technology, lowadded-value sectors with declining demand, as strong FDI inflows to the CEEC has led to an increasing preponderance of more dynamic sectors in their export structures. Thus it is also "being squeezed from above". This suggests that there may be substantial industrial disruption, in response to which labour-market flexibility and dynamic entrepreneurial response is crucial. A worrying aspect of this is that intersectoral mobility is generally easier the more highly educated the workforce - an indicator on which Portugal scores quite poorly.

For this reason, amongst others, many of the CEE countries are in a more favourable position than Portugal with respect to future FDI inflows. Several have followed Ireland's lead in offering low rates of corporation taxes, the more advanced ones have more highly skilled populations, and labour costs are generally lower than in Portugal. Upon accession, they will have equally easy access to the high-income markets

integrated with the country's FDI-oriented industrialisation strategy - appears to help explain its convergence. 
of Western Europe and, if they learn their lessons correctly, are likely to enjoy stable macro policy environments and regulatory and public administration systems equivalent to those elsewhere in the EU. This opens up the possibility that they might compete directly with Portugal, Spain and Ireland for FDI, as argued by Barry (2003). There is indeed some evidence that this is already occurring in the case of Southern Europe. Portugal may be particularly adversely affected given the relatively low human-capital stock and deficiencies in the efficiency of the government sector.

While the former, in terms of education and training, can only be tackled as part of a long-term development strategy, public-sector deficiencies and flaws in the conduct of macroeconomic policy can be tackled more easily - if the political will to do so is present.

Enlargement will also open up the possibility of more substantial labour migration. Most studies estimate that inflows will be quite modest, with the majority of migrants going to Germany and Austria. Portugal will receive only a very limited fraction of these flows. The impact on wages and living standards will depend on the skills of the migrants but if inflows are as modest as most studies suggest, these effects will be fairly negligible. We have pointed out the possibility however that Portuguese emigrants may be crowded-out from traditional destinations, putting further pressure on the Poruguese labour market.

The implications of enlargement may be particularly adverse with respect to the country's eligibility for Structural Funds post-2006. The low average per capita income of the CEEC will lead to the Cohesion Countries losing a large part of the funds they have been receiving in recent years. Also as a consequence of the enlargement, two Portuguese regions (Algarve and Madeira) will lose their Objective 1 status.

Portugal indeed may well stand to lose most from enlargement, as Baldwin et al. (1997) and Breuss (2001) suggest. Nevertheless, the capacity to respond to this is endogenous. One recalls historian Arnold Toynbee's theory of "challenge and response", developed in his Study of History. All cultures and societies face various challenges. It is their capacity to respond to these challenges that determines their success or failure. 


\section{References}

Baldwin, R., J. Francois and R. Portes (1997), "The Costs and Benefits of Eastern Enlargement: the Impact on the EU and Central Europe", Economic Policy, 24:125-76.

Barry, F. (2003), "EU Accession and Prospective FDI Flows to CEE Countries" in R. Lipsey and H. Herrmann (ed.) Foreign Direct Investment in the Real and Financing Sector of Industrial Countries, Deutsche Bundesbank/Springer Verlag (forthcoming).

Barry, F. and A. Hannan (2003a), "Product Characteristics and the Growth of FDI", Working Paper 03/08, University College Dublin, available at: http://www.ucd.ie/ economic/workingpapers/2003.htm

Barry, F. and A. Hannan (2003b), "FDI and the Predictive Powers of Revealed Comparative Advantage Indicators", unpublished ms., University College Dublin.

Bauer, T. and K. Zimmermann (1999), “Assessment of Possible Migration Pressure and its Labour Market Impact Following EU Enlargement to Central and Eastern Europe", IZA Research Report No. 3, Bonn.

Blomström, M. , A. Kooko and M. Zejan (2000), Foreign Direct Investment - Firm and Host Country Stategies, New York: Palgrave.

Boeri, T. and H. Brücker (2000), "The Impact of Eastern Enlargement on Employment and Labour Markets in the EU Member States", DIW, CEPR, FIEF, IGIER, HIS, Berlin and Milano.

Braconier, H. and K. Ekholm (2001), "Foreign Direct Investment in Central and Eastern Europe: Employment Effects in the EU”, CEPR Working Paper No. 3052.

Breuss, F. (2001), "Macroeconomic Effects of EU Enlargement for Old and New Members", Working Paper No. 143, Austrian Institute of Economic Research (WIFO).

Brücker, H.(2001), “ The Impact of Eastern Enlargement on EU-Labour Markets”, CEPII Working Paper No. 01/05.

Caetano, J. A. Galego, E. Vaz, C. Vieira and I. Vieira (2002), "The Eastward Enlargement of the Eurozone - Trade and FDI", Ezoneplus Working Paper No. 7

CEPR(2002), “Who's Afraid of the Big Enlargement?", Policy Paper No. 7, Centre for Economic Policy Research, London.

de la Fuente and R. Doménech (2001), “ The Redistributive Effects of the EU Budget: an Analysis and Proposal for Reform", Journal of Common Market Studies, 39 (2): 307-30. 
Dunning, J. (1997a), "The European Internal Market Programme and Inbound Foreign Direct Investment”, part 1, Journal of common Market Studies, 35 (1):1-30.

Dunning, J. (1997b), "The European Internal Market Programme and Inbound Foreign Direct Investment, part 2, Journal of common Market Studies, 35 (2), pp.189-223.

European Commission (1999), Second Report on Economic and Social Cohesion, Luxembourg.

Fernandes, C. (2002), "The Changes in International Trade Structure and the Evolution of Portugal Trade Specialisation compared to the "Triad": the Challenges of International Competitiveness", Paper Delivered at 5th. International Workshop on European Economy, CEDIN/ISEG, Lisbon, 22-23 November.

Flôres, R. , M. Fontoura and R. Santos (2002), "Foreign Direct Investment Spillovers: Additional Lessons from a Country Study", Ensaios Económicos da EPGE, no 455, Fundação Getúlio Vargas, Rio de Janeiro.

Freundenberg, M. and F. Muller (1991), "La Structure du Commerce Extérieur de la RFA et de la France en 1989: Une Analyse Empirique de la Structure du Commerce et Gammes Échangées", Université Paris I Panthéon- Sorbonne.

Leite, N., J. Machado and V. Cúrdia (2001), Portugal como Destino do Investimento Directo Estrangeiro - Estudo da Competitividade da Economia Nacional , Câmara de Comércio Americana em Portugal.

Lejour, A., R. de Mooij and R. Nahuis (2001), "EU Enlargement Economic Implications for Countries and Industries", Central Planning Bureau of the Netherlands, Working Paper No. 585.

Martín, C., J. Herce, S. Sosvilla-Rivero and F. Velázquez (2002), La Ampliación de la Unión Europea - Efectos sobre la Economia Española, Colección Estudios Econòmicos No.27.

Ministry of Economy (2002), O Alargamento da UE - Reflexão no Ministério da Economia, Direcção - Geral das Relações Económicas Internacionais.

OECD(2001), Education at a Glance, Centre for Economic Research and Innovation, Paris, OECD.

Pavelin, S. and F. Barry (2003) "The Single Market and the Diversification of Leading Firms in the EU", Working Paper 03/05, University College Dublin, available at: http://www.ucd.ie/ economic/workingpapers/2003.htm

Peixoto, J. (1999), A Mobilidade Internacional dos Quadros - Migrações Internacionais, Quadros e Empresas Transnacionais em Portugal, Oeiras, Celta Editora 
Peixoto, J. (2002), "Strong Market, Weak State: the Case of Recent Foreign Immigration in Portugal", Journal of Ethnic and Migration Studies, vol 28, n 3: 483-497.

Pires, R. (2002), "Mudanças na imigração-uma análise das estatísticas sobre a população estrangeira em Portugal, 1998-2001”, Sociologia-Problemas e Práticas, n 39: 151-66.

Pelkmans, J. (2001), European Integration - Methods and Economic Analysis, 2nd edition, Essex: Prentice Hall.

Porto, M. (2002), “A Política Regional na União Europeia” in J. Costa (ed.) Compêndio de Economia Regional, APDR.

Proença, I., M. Fontoura and N. Crespo (2002), "Productivity Spillovers from Multinational Corporations in the Portuguese Case: Evidence from a Short Time Period Panel Data", Working Paper 6/2002, Department of Economics, ISEG, Technical University of Lisbon.

Rita, J.(2002),'Imigração Económica e Competitividade: Dilemas dos Mercados de Trabalho" in Imigração e Mercado de Trabalho, Departamento de Estudos, Prospectiva e Planeamento, Ministério da Segurança Social e do Trabalho, Celta Editora.

Schürmann, C. and A. Talaat (2000), "Towards a European Peripherality Index", Report for European Commission DG XVI Regional Policy.

UNCTAD (2001), World Investment Report. 